\title{
The Electronic Management and its Role in Achieving Organizational Success - An Analytical Applied Research in the Directorate General for Industrial Development $\backslash$ Iraq
}

\author{
Rusul Rowdan Asei ${ }^{1}$ Ayman Hadi Talib ${ }^{2}$ Ahmed Hadi Talib ${ }^{3}$ \\ ${ }^{I}$ Directorate General for Industrial Development ${ }^{2}$ Directorate General for Vocational Education \\ ${ }^{3}$ University of Babylon, Faculty of Management and Economics
}

rsool1977@gmail.com aymentalib@ vocational.edu.iq bus.ahmed.hady@uobabylon.edu.iq

Submission date:- 29/7/2018 Acceptance date:- 5/9/2018 Publication date:- 15/1/2019

Keywords: Organizational Success, Organizational Success Criteria, Electronic Management, Electronic Management Dimensions.

\begin{abstract}
The research has aimed to demonstrate the role played by electronic management in achieving organizational success. It represents a wide area for entering the business world in interaction and communication with modern trends. The current environment is very competitive. As the goal that all organizations seek to achieve, the research in the general directorate for industrial development followed one of the organizations that oversees the development of the private and mixed industrial sector in Iraq. The research based on a basic assumption that there was a significant relationship between electronic management and the possibility of organizational success. The descriptive approach adopted on the theoretical and analytical side of statistics in the applied side, which with based on a questionnaire developed to suit the nature of the research and its objectives. It distributed to different administrative levels. After analyzing, the answers based on the appropriate statistical methods and specialized programs in statistical analysis, of the conclusions and recommendations that would develop, distinguish and transfer the quality of the administrative process to ensure organizational success.
\end{abstract}

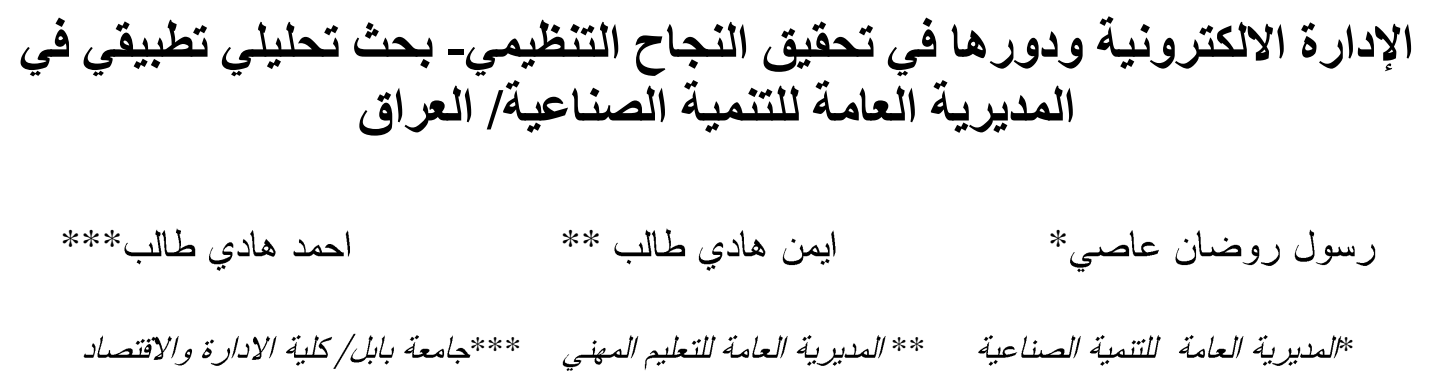

rsool1977@gmail.com aymentalib@vocational.edu.iq_bus.ahmed.hady@uobabylon.edu.iq 
اختلافها، طبق البحث في المديرية العامة للنتمية الصناعية بعدّها واحدة من المنظمات التي تشرف على تطوير القطــاع الصــناعي الخاص و المختلط في العراق. بني البحث على أساس فرضية رئيسية مفادها (توجد علاقة ذات دلالة معنوية بين الإدارة الاككترونية

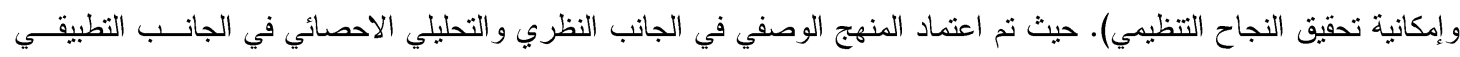
الذي اعتمد على استبانة نم تطوير ها لتتاسب طبيعة البحث و أهدافه نوزيعها على مختلف المستويات الإدارية فــي المديريسـة محـل

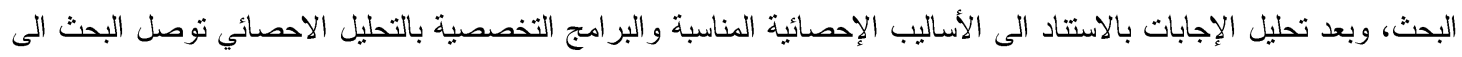

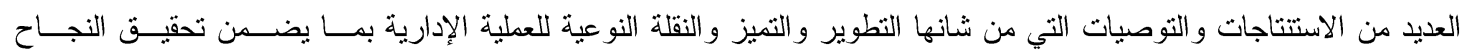

الكلمات الدالة: النجاح النتظيمي، معايير النجاح التتظيمي، الإدارة الالكترونية، أبعاد الإدارة الالكترونية.

\section{المقدمة}

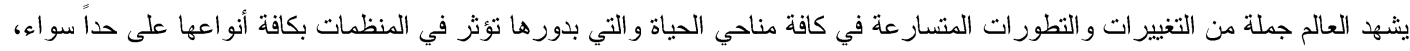

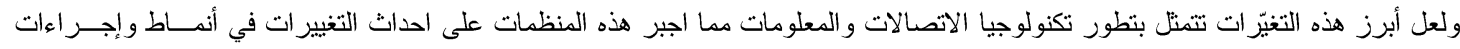
العمل للوصول الى النجاح الذي تصبوا اليه هذه المنظمات.

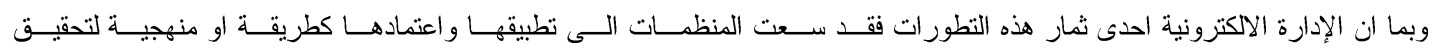

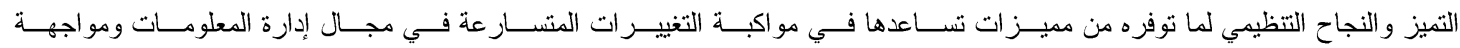

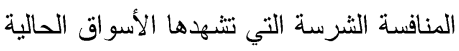

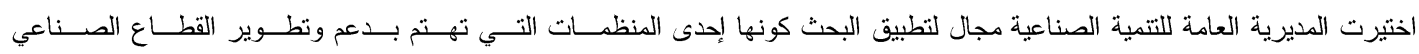

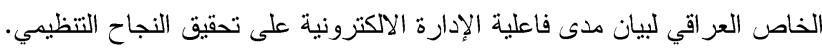

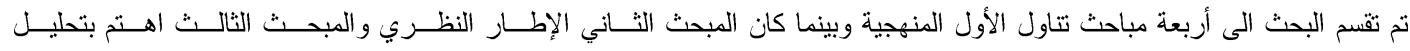

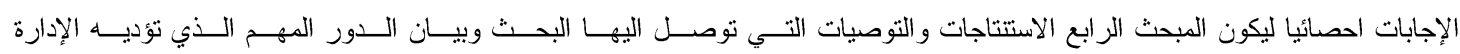

\section{1- المنهجية العلمية للبحث}

1. 1. (1) مشكلة البحث

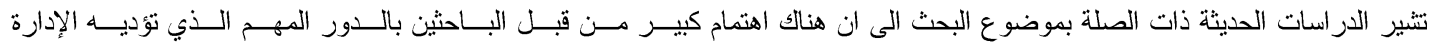

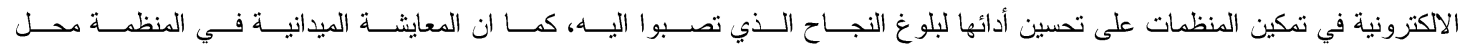

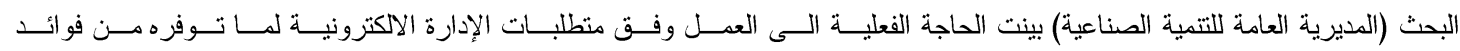

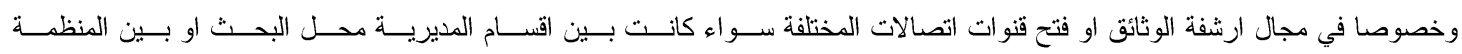

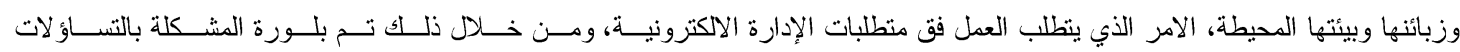

1- هل يمتلك المدراء تصوراً و اضحا حول المبادئ الاساسية لتطبيق الادارة الالكترونية ومفهومها و عناصر ها وفو ائدها ومتطلبات تتفيذها؟

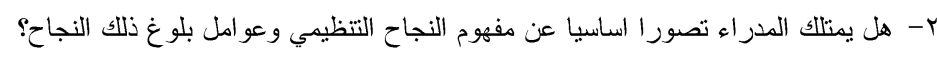
r- ما مدى اسهام تطبيق الإدارة الالكترونية في تحقيق النجاح التنظيمي؟ باء ع - هل تتوفر في المنظمة محل البحث البنى التحتية اللازمة لتطبيق الادارة الآكترونية بشكل يسهم في تحقيق النجاح التتظيمي؟

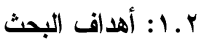

يسعى البحث الى تحقيق مجموعة من الأهداف تتمثل بالآتي: 1- التعريف بمفهوم الادارة الالكترونية الذي يعد من المفاهيم الحديثة وابراز البنى التحتية الضرورية والكئية الكفيلة لنجاح تطبيقها.

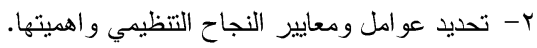
r- تسليط الضوء على و اقع الادارة الالكترونية في المديرية العامة للتنمية الصناعية. ع- تعريف العاملين في المنظمة محل البحث بأهمية الادارة الالكترونية.

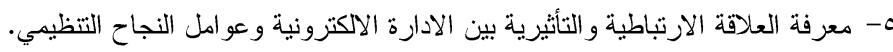
צ- التعرف على المعوقات التي قد تواجه تطبيق الادارة الالكترونية في المديرية العامة للتتمية الصناعية. 
ب. ا: الهية البحث

1- تتاول لموضو ع يتسم نوعا ما بالحداثة من خلال اعتماد نظام الادارة الالكترونية في منظمات نقديم الخدمة.

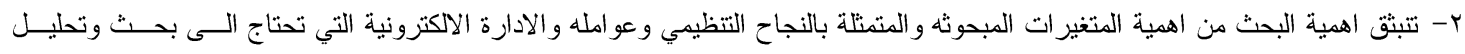
لنانتمس معطياتها في المنظمات. r- ابراز الجانب التطبيقي للإدارة الالكتزونية والذي يسهم في تحقيق النجاح التنظيمي.

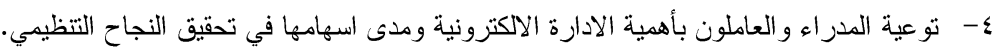

ع. ا: فرضيات البحث

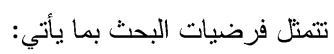

الفرضية الرئيسة الاولى: توجد علاقة ارتباط ذات دلالة معنوية بين (تطبيق الادارة الاككترونية وتحقيق النجاح التظيمي) و التي يتقرع عدد من

الفرضيات الفرعية وكما يأتي:

1- الفرضية الفرعية الاولى (توجد علاقة ارتباط ذات دلالة معنوية بين عناد الحاسوب وتحقيق النجاح التنظيمي). r- الفرضية الفرعية الثانية (توجد علاقة ارتباط ذات دلالة معنوية بين البرامجيات وتحقيق النجاح التنظيمي).

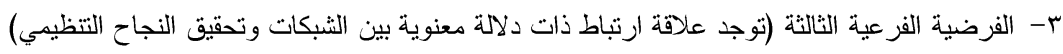

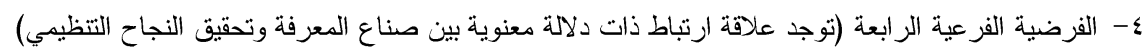
الفرضية الرئيسة الثانية: (توجد علاقة تأثير ذات دلالة معنوية بين تطبيق الادارة الالكترونية وتحقيق النجاح التنظيمي) والتي يتفر ع منها عدد من الفرضيات الفرعية التالية: الفيه: 1- الفرضية الفزعية الاولى (توجد علاقة تأثير ذات دلالة معنوية بين عناد الحاسوب وتحقيق النجاح التنظيمي).

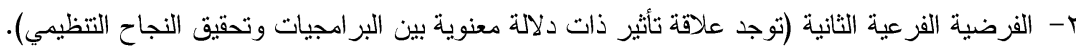

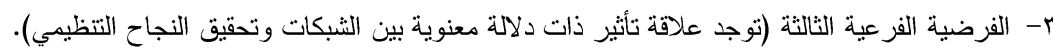
ع - الفرضية الفز عية الرابعة (توجد علاقة تأثير ذات دلالة معنوية بين صناع المعرفة وتحقيق النجاح التنظيمي).

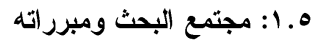

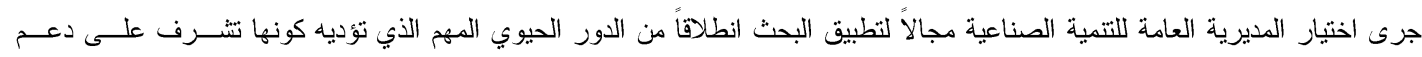

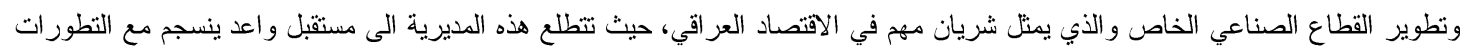
الحديثة في مجال تكنولوجيا المعلومات.

1. 1.

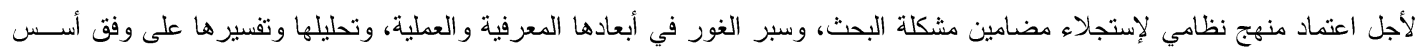

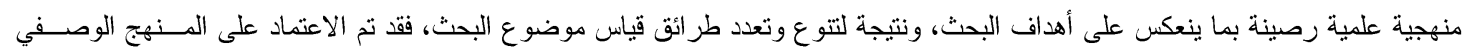

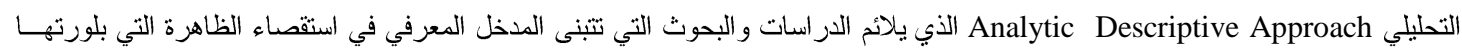

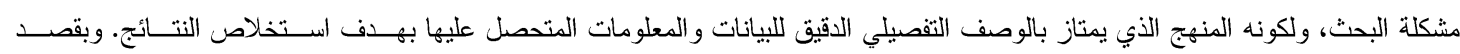

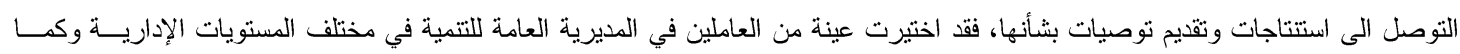

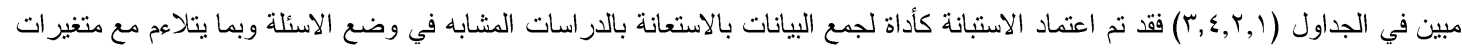
البحث و المنظمة محل البحث.

\begin{tabular}{|c|c|c|c|}
\hline النسبة المؤية & العدد & الجنس & ت \\
\hline$\% 0$. & $\mu$ & ذكر & 1 \\
\hline$\% 0$. & Tा & انثى & $r$ \\
\hline$\% 1 \ldots$ & Tr & المجموع & \\
\hline
\end{tabular}




\begin{tabular}{|c|c|c|c|}
\hline النسبة المؤية & العدد & المنصب & ت \\
\hline$\% \cdot, r$ & r & معاون مدير عام & 1 \\
\hline$\% \wedge$ & 0 & مدير قسم & r \\
\hline$\% 10$ & 9 & وكيل قسم & r \\
\hline$\% 10$ & 9 & مسؤول شعبة & $\varepsilon$ \\
\hline$\% 4$. & rv & موظف & o \\
\hline$\% 1 \ldots$ & it & المجموع & \\
\hline
\end{tabular}

\begin{tabular}{|c|c|c|c|}
\hline النسبة المؤية & العدد & التحصيل الار اسي & ت \\
\hline$\% r$ & 1 & ماجستير & 1 \\
\hline$\%$ & $r$ & دبلوم عالي & $r$ \\
\hline$\% \vee \leqslant$ & $\leq 4$ & بكالوريوس & r \\
\hline$\% 1 r$ & $\wedge$ & دبلوم & $\varepsilon$ \\
\hline$\% 4$ & $\varepsilon$ & اعدادية & 0 \\
\hline$\% 1 \ldots$ & Ir & المجموع & \\
\hline
\end{tabular}

جدول (ع) مدة الخدمة لعينة البحث

\begin{tabular}{|c|c|c|c|}
\hline النسبة المؤية & العدد & مدة الخدمة & $ت$ \\
\hline$\% 4$ & $\varepsilon$ & اقل من · ا سنوات & 1 \\
\hline$\% \leq r$ & ry & اكثر من · ا و اقل من ·r سنة & $r$ \\
\hline$\% r \varepsilon$ & rr & اكثر من ·r و اقل من ·r & r \\
\hline$\% \backslash \wedge$ & 11 & اكثر من •r سنة & $\varepsilon$ \\
\hline$\% 1 \ldots$ & Tr & المجموع & \\
\hline
\end{tabular}

1.V

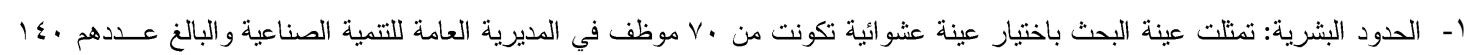

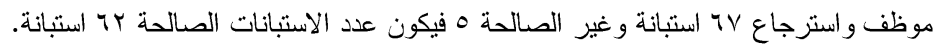

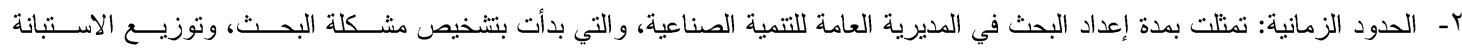

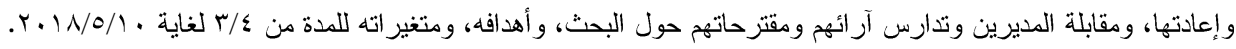

^.ا: مصادر جمع البيانات

اعتمد البحث على عدد من الوسائل التي بوساطتها تم جمع البيانات و المعلومات حول عينة البحث وتحليلها وبحسب الآتي: -

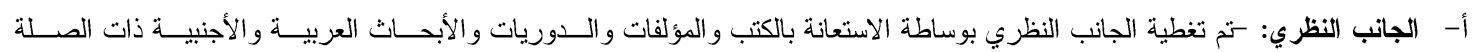
بالموضو ع فضلاً عن استخدام الثبكة الدولية (الانترنت).

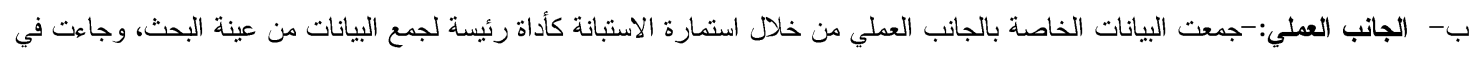

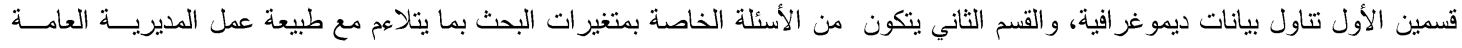

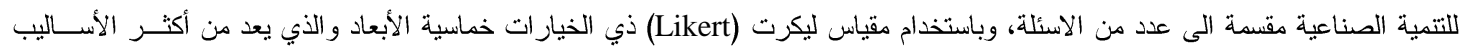

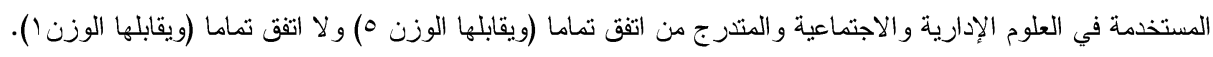


1. 1. الاختبار ات الخاصة باسنمارة الاستبيان

1- إقاقية الاستبانة:

أ- اختبار الصدق الظاهري للاستبانة: بعد تصميم الاستبانة وصياغة عبار اتها عرضت على مجموعة من الخبراء و الاساتذة كمكمين للتعـرف

على آر ائهم في محاور الاستبانة والاسئلة التي تتدرج تحته ومدى اتساق كل محور من محاور الاستييان مع الهدف الرئيس للبحث.

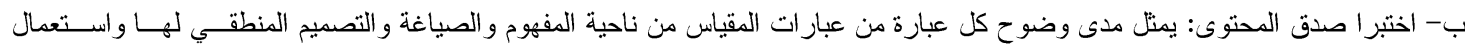

معادلة الفاكرونباخ.

r- الغرض من بيان ثبات الاستبانة: هو للتأكد من ان المقياس المستخدم يعطي النتائج نفسها ان اعيد تطبيقها بعد مدة مـن الــزمن علـى ذات

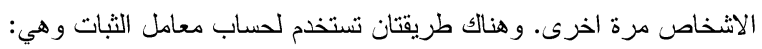

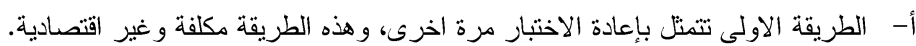

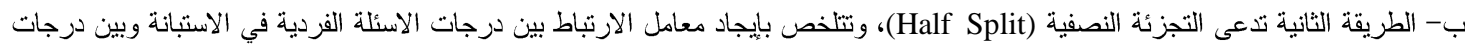

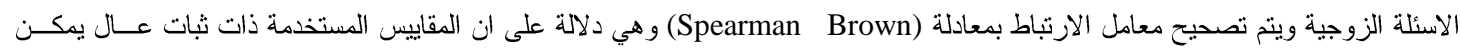
اعتماها في اوقات مختلفة للأفر اد أنفسهم وتعطي النتائج ذاتها.

• 1. 1: وسائل التحليل و المعالجة الاحصائية

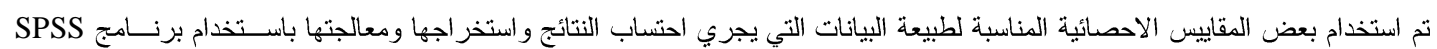
لتحقيق اهداف البحث والاختبار ات الاحصائية المستخدمة وهي: الإئية 1- الوسط الحسابي(Mean) لتحديد مستوى المتغير ات و اتجاهات واجابات افز اد العينة ضمن العن مقياس الاجابة.

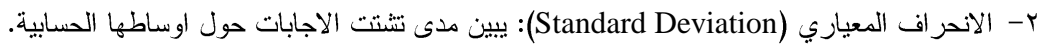
r- التباين(Variance): هو مقياس لاختلاف البيانات ونتشتها، وهو متوسط مربعات انحر افات التهات القيم عن وسطها الحسابي.

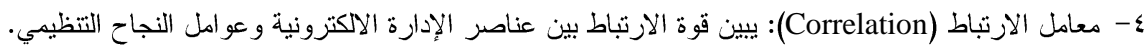

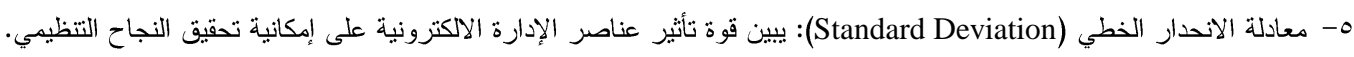
؟- معامل الفا كرونباخ (Alpha Cronbach): يستخدم في قياس مدى صدق الاستبانة.

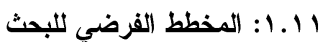
في ضوء الاتجاهات التي وردت في الجانب النظري للبحث و التي استتدت على اطروحات مجموعة من الباحتين تم صياغة النموذج الفرضـي

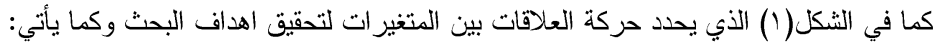

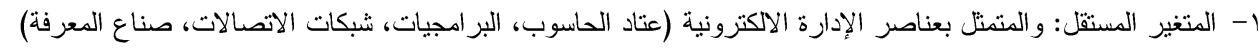

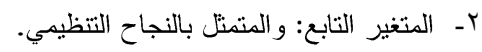

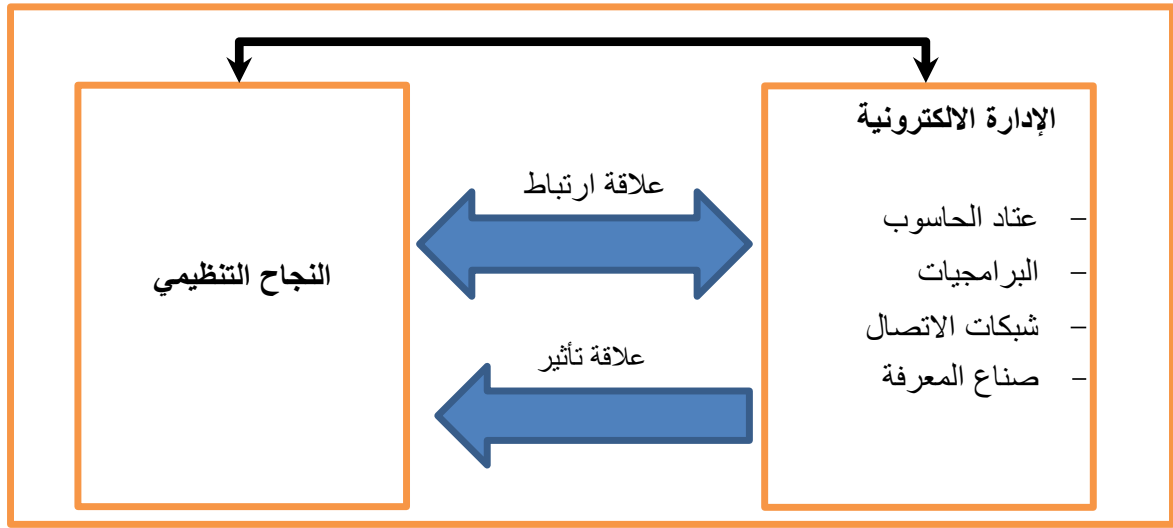

شكل (1) مخطط البحث الفرضي 


\section{r- (الجانب النظري}

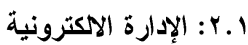

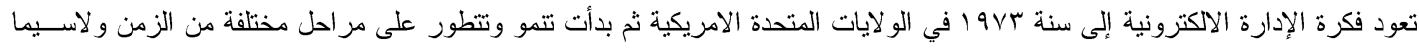

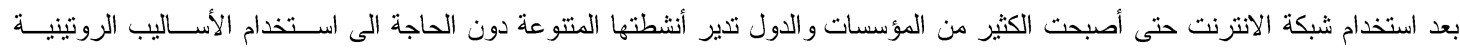

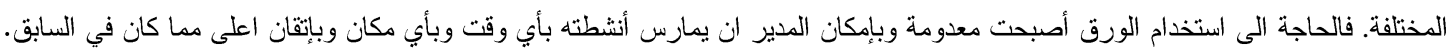

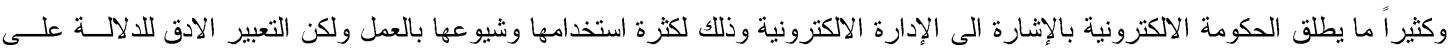
المقصود هو الإدارة الالكترونية [ل] يشير مصطلح الإدارة الالكترونية الى التحول والاتتقال من الإدارة التقليدية في انجاز الاعمال وتقديم الخدمات والاستفادة القصوى مما توفزه الإدها

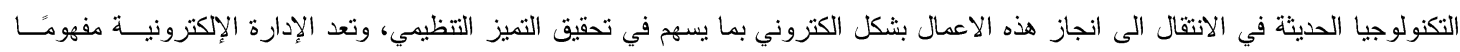

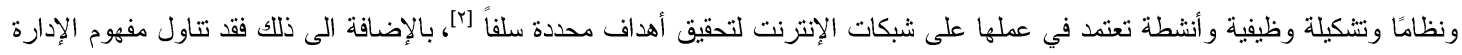

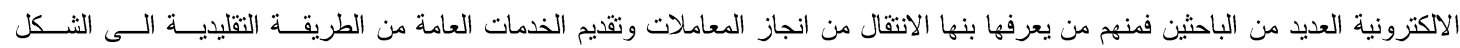

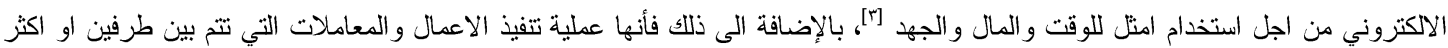

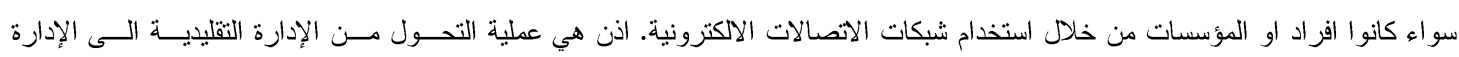

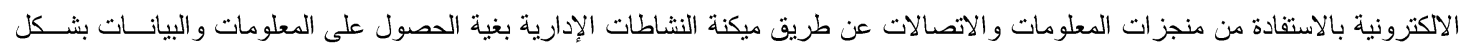

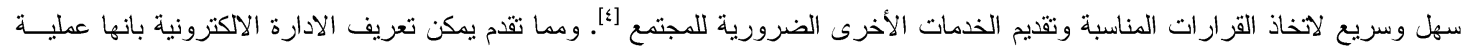

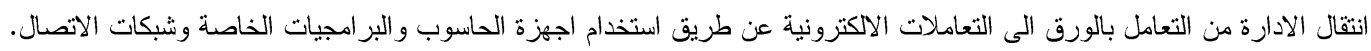

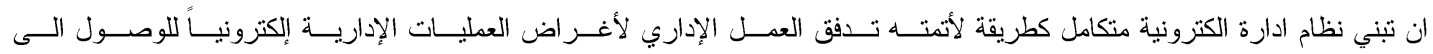

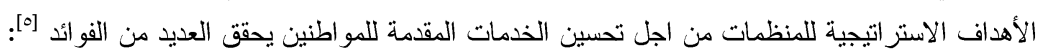

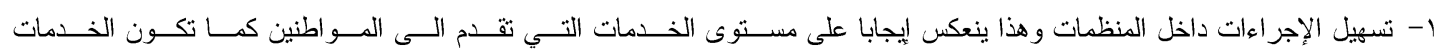

أكثر جودة.

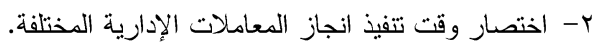

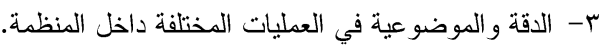

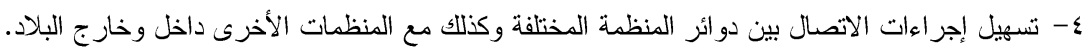

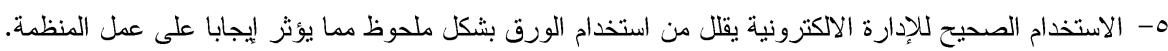

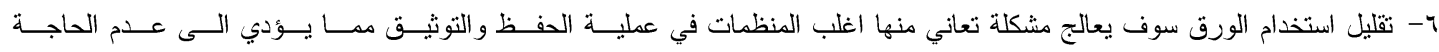
لاماكن تخزين حيث يتم الاستفادة منها في أمور أخرى. تلفئ.

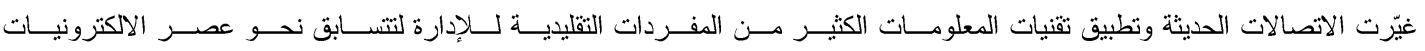

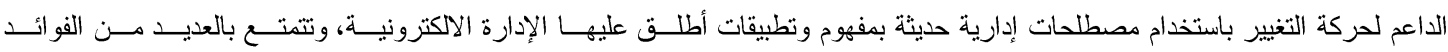

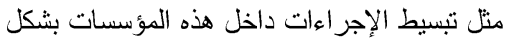

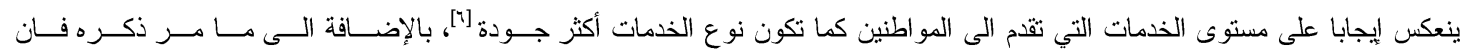

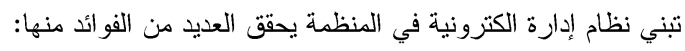

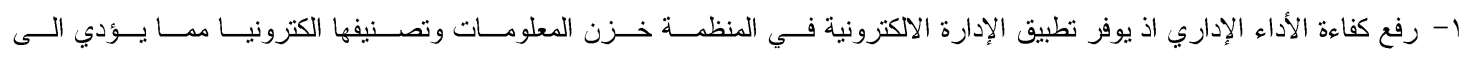

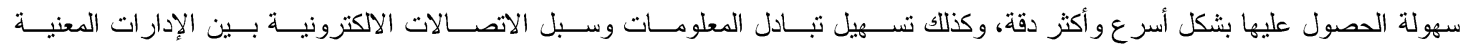

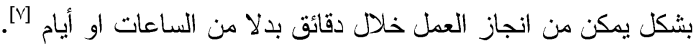

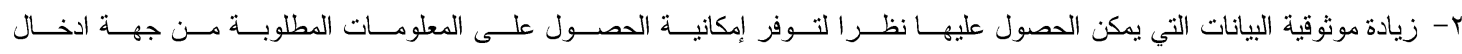

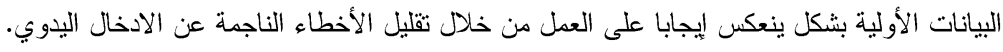

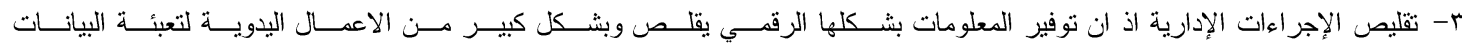

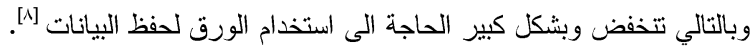

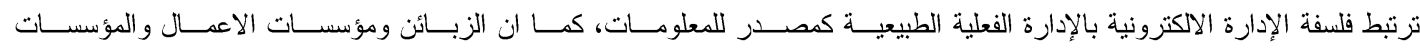

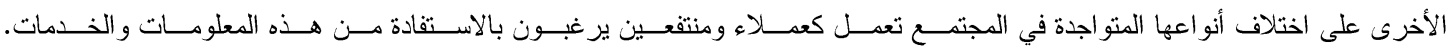

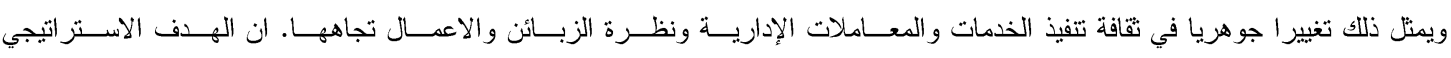

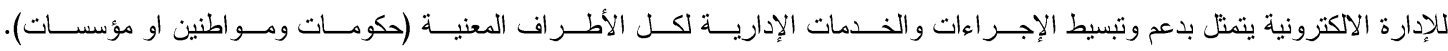

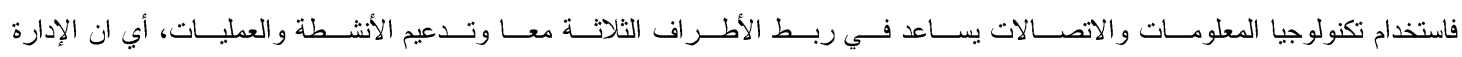

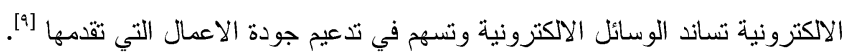

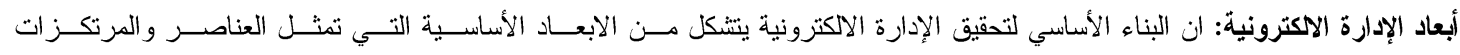

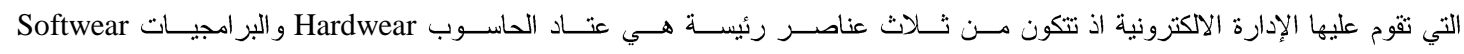




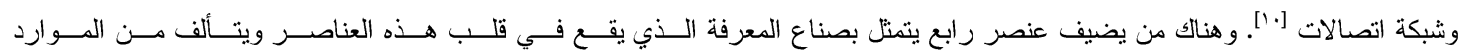

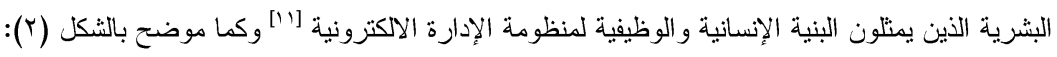

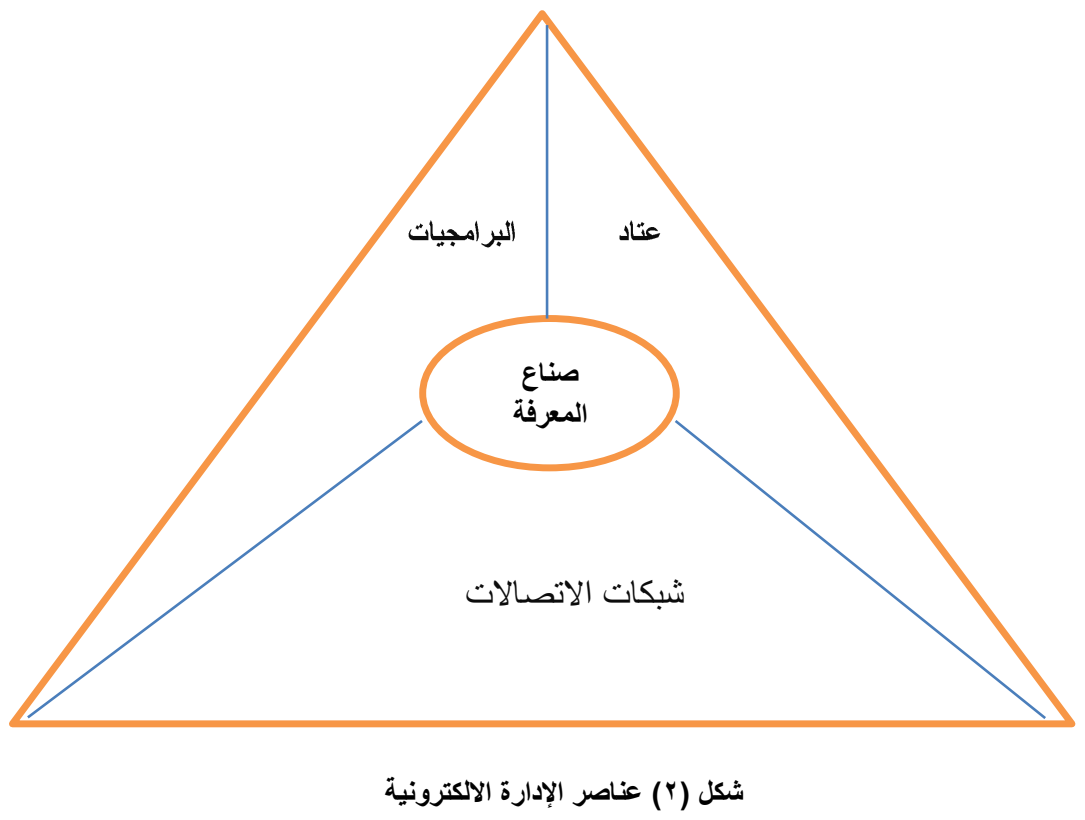

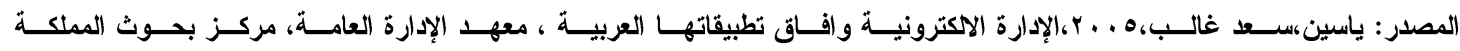

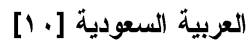

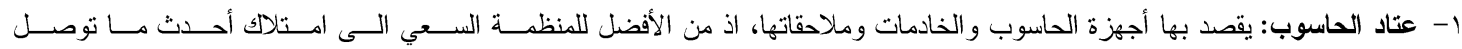

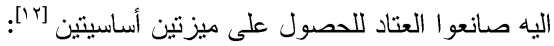

أ- ت توفر تكاليف التطوير المستمرة وتكاليف الصيانة. ب- بلائمة العتاد للتطورات البرمجية وبر امجيات نظم المعلومات.

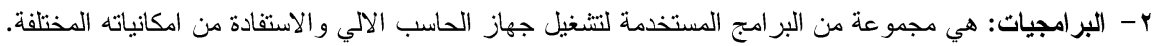

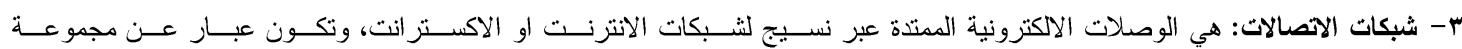

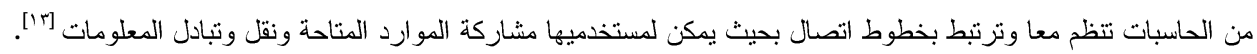

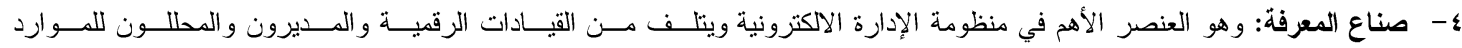

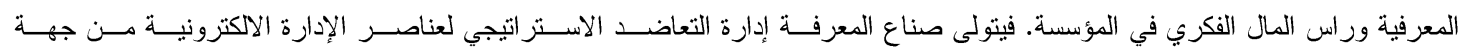

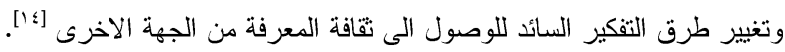

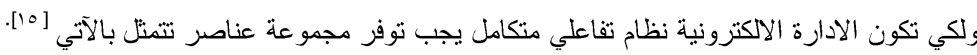

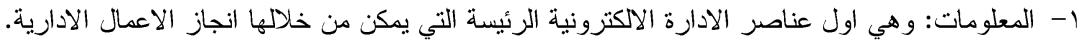

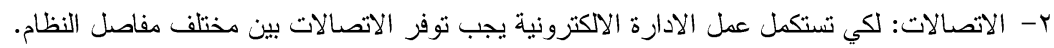

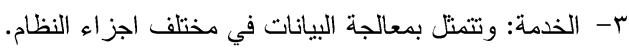
متطلبات تطبيث الإدارة الاكترونية

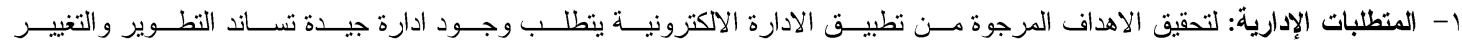

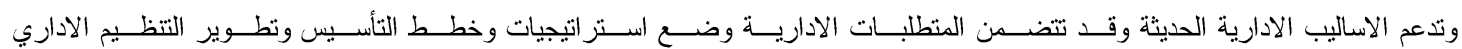

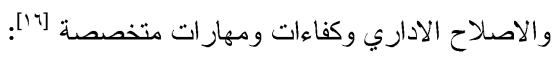

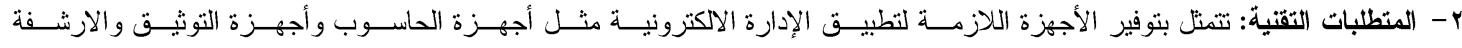
الالكترونية وأجهزة ربط الثبكات و الخو ادم و غير ها.

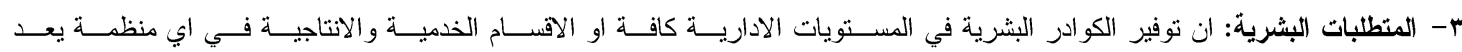

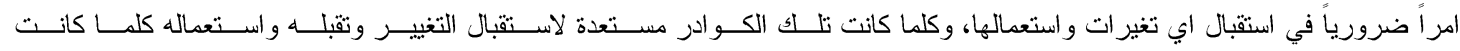

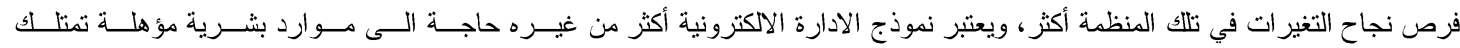

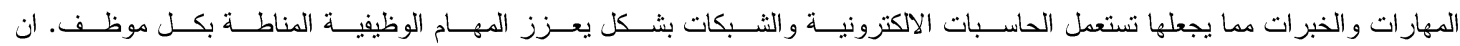




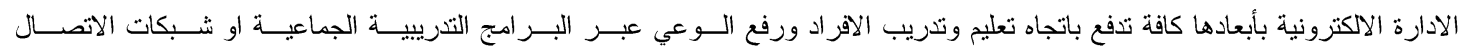

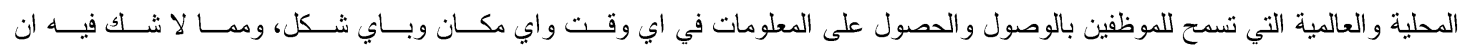

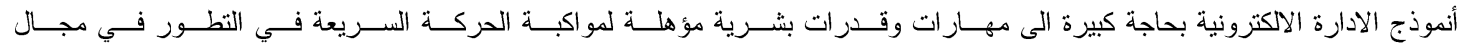

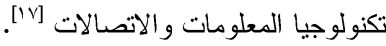

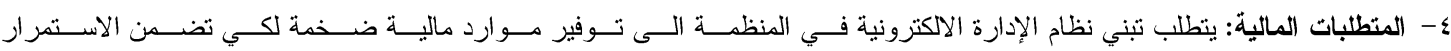

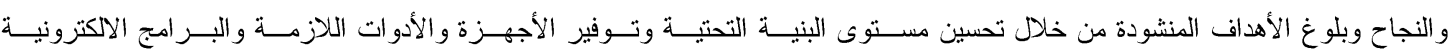

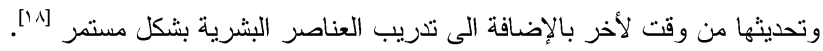

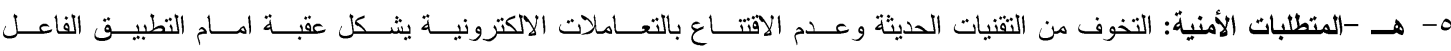

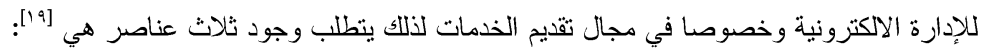

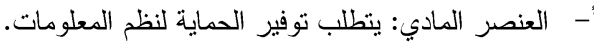
ب- العنصر التقني: استخدام التقنيات الحديثة في دعم وحماية امن المعلومات العئ.

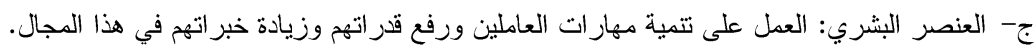

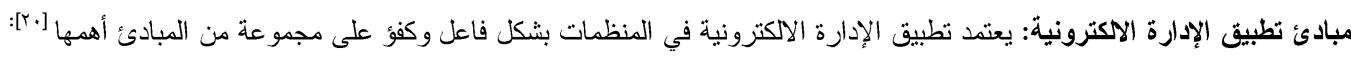

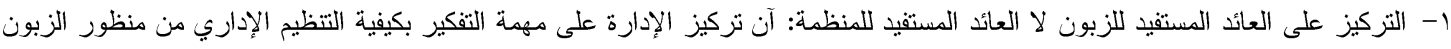
او المستفيد والخدمات التي يمكن ان تقدمها لـه.

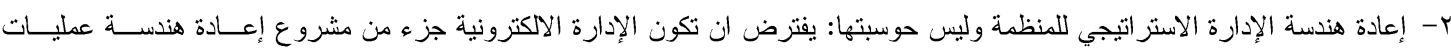

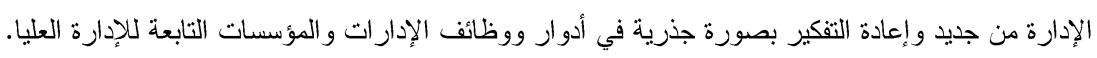

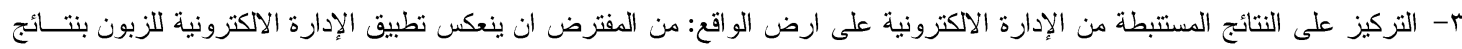
إيجابية من حيث تخفف العبء عنه من خلال تقليل الجهد و المال و الوقت.

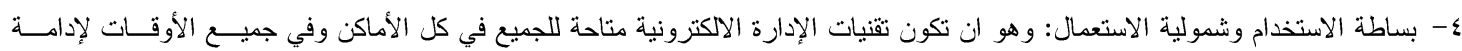

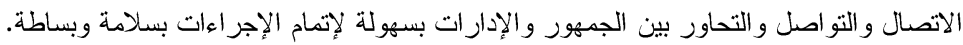
0- التمييز بين شفافية المعلومات والخصوصية: ينبغي احتر ام خصوصية المعلومات الخاصة بالأفراد على مختلف تصنيفاتهم (زبائن، عـاملون) من حيث حسن استخدام المعلومات وتداولها و الحفاظ على سريتها.

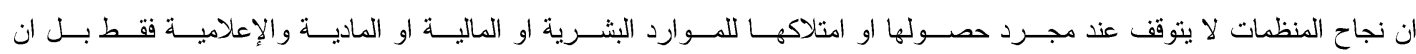

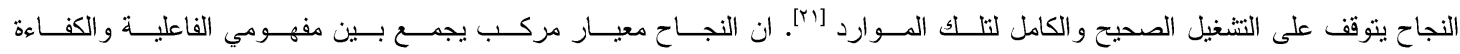

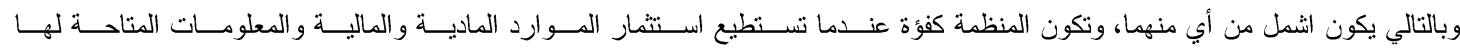

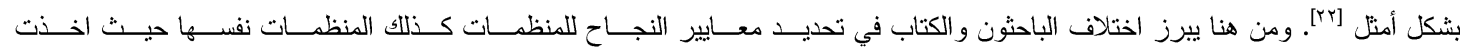

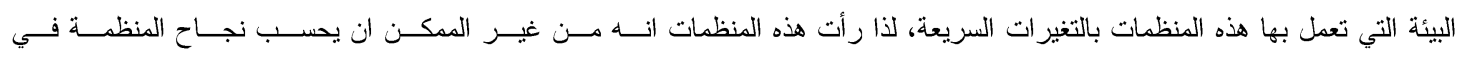

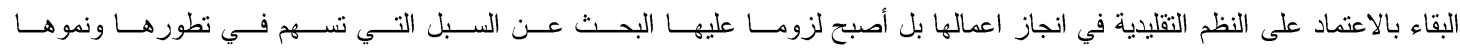

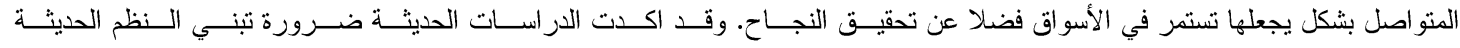

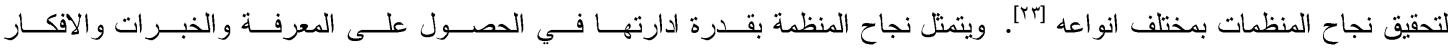

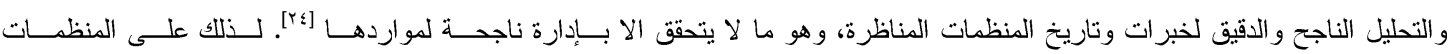

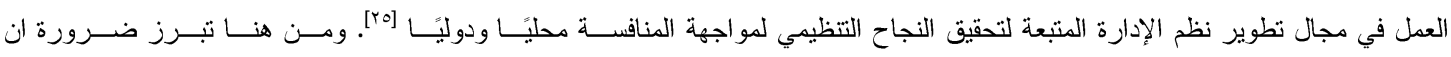

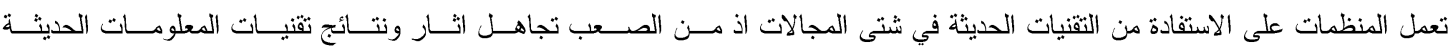

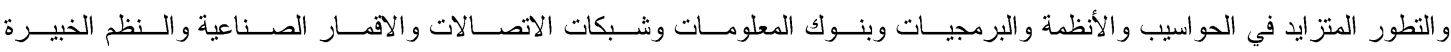

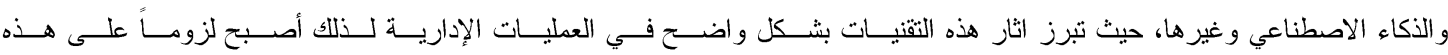

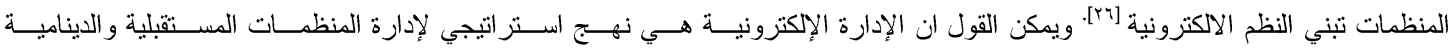

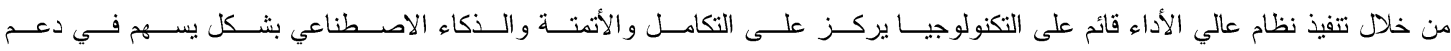

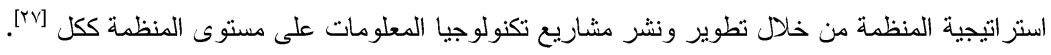

r.r معظم المنظمات لديها اهداف ترغب في تحقيقها و على اختلاف انو اعها وبالتالي تحتاج الى تحديد عو امل تمكنها من تحقيق النجاح الذي يمثل

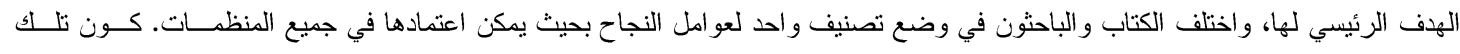

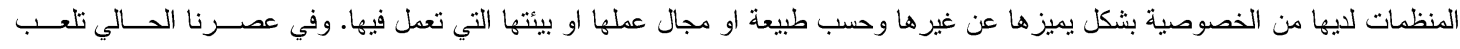




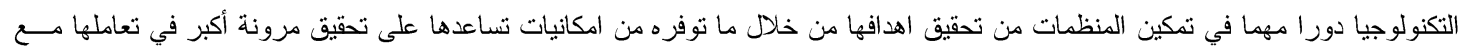

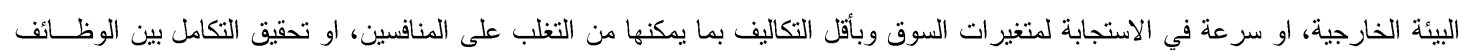
على مختلف المستويات، او تساعدها على الابتكار في تقديم خدمات او سلع جديدة.

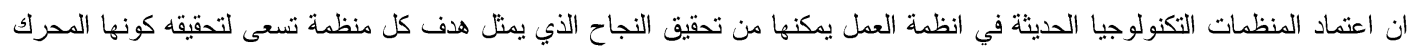

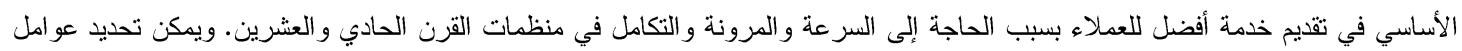

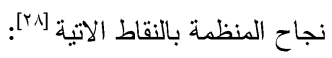

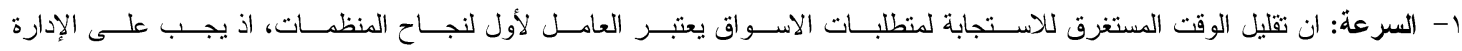

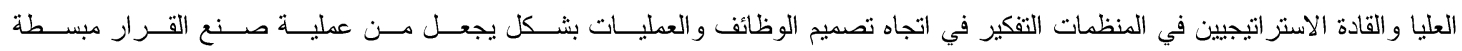

و غير معقدة وسريعة.

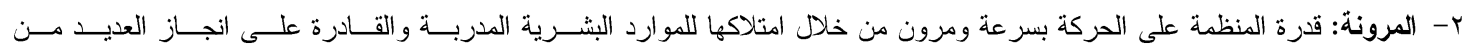

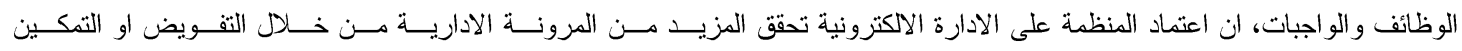

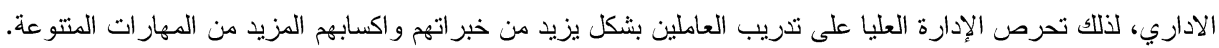

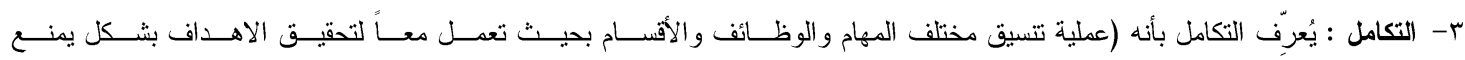

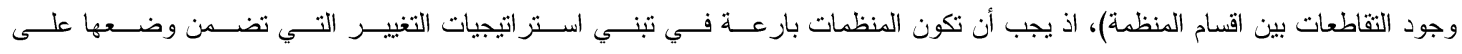

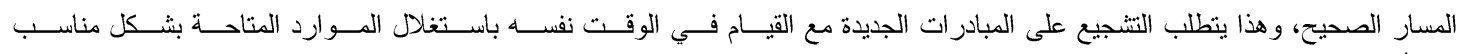

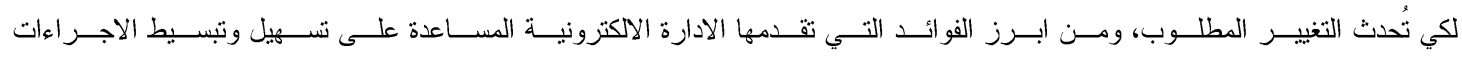

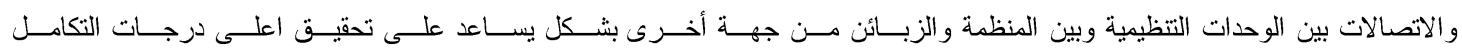
المنشودة.

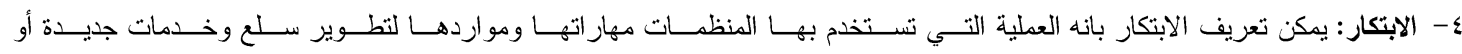

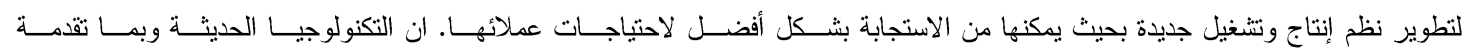

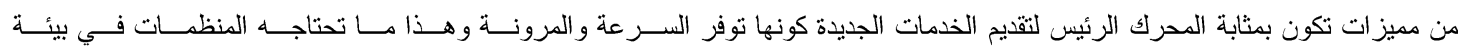

؛.ب: المديرية العامة للتنمية الصناعية

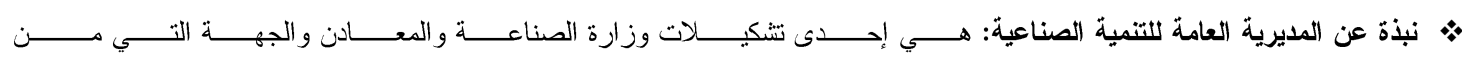

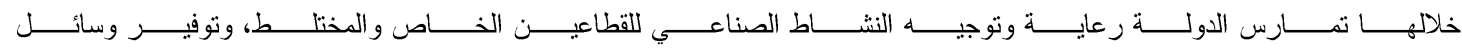

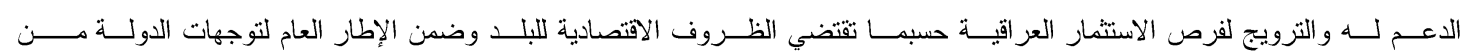

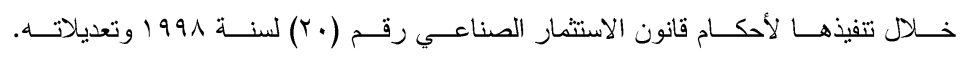

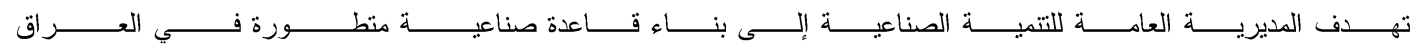

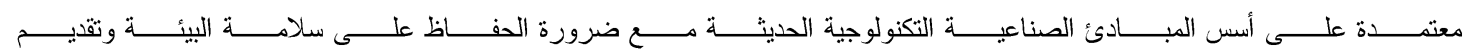

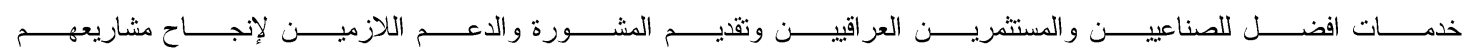

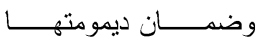

ها م واقع الادارة الاكترونية في المديرية العامة للتنمية الصناعية: سعت المديرية العامة للتتمية الصناعية على مر السنين منذ التأسيس الى يومنا

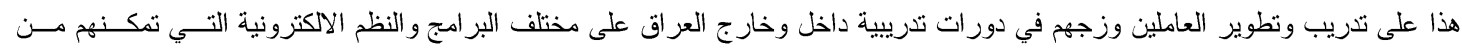

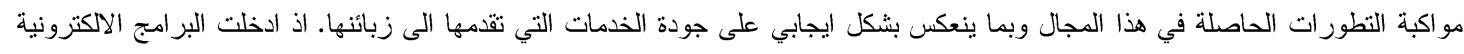
في انظمة العمل ومن خلال المر احل الاتية والتي تمثل مر احل اعتماد الادارة الالكترونية في المديرية العامة للتنمية الصناعية:

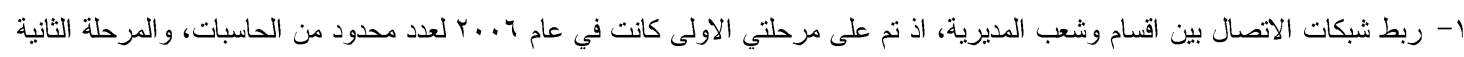

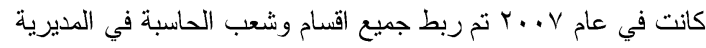

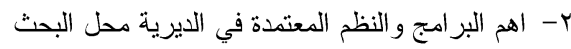
أ- نظام توثيق المشاريع الصناعية: بدا العمل على هذا البرنامج منذ عام 991 اويمثل اللبنة الاولى لإدخال اجهزة الحاسوب في انظمة العمـلـل.

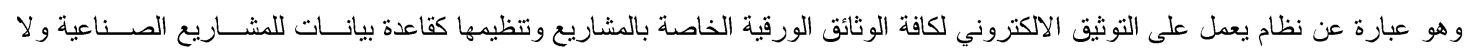
يتطلب هذا البرنامج الى ربط الثنبكات.

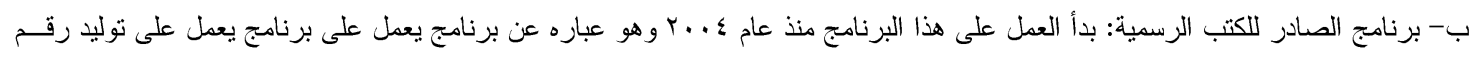

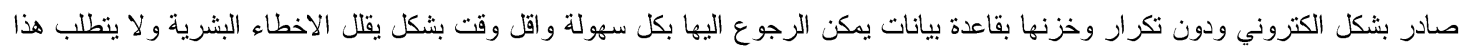
البرنامج الى ربط الثبكات. 
ج- نظام الموارد البشرية: بدا العمل على هذا النظام عام ؟ج . ب ويختص بيانات الموظفين الاساسية توفير قاعدة بيانات دقيقة يمكن الوصول اليها

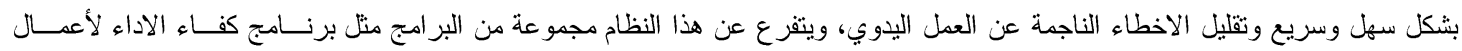
المديرية ونظام الاجاز ات و الرو اتب و وغير هاء.

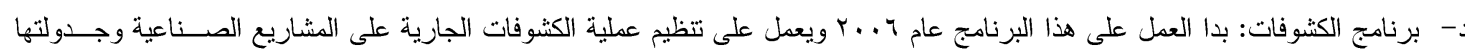

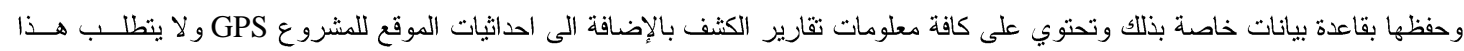
البرنامج الى ربط الثبكات.

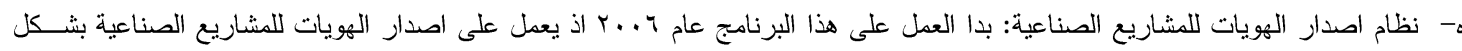

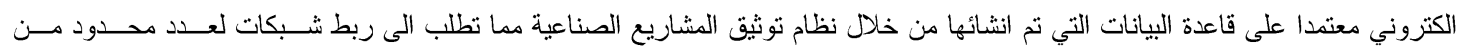

الحاسبات فكانت المرحلة الاولى للاربط الشبكي في المديرية.

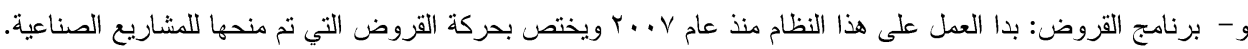

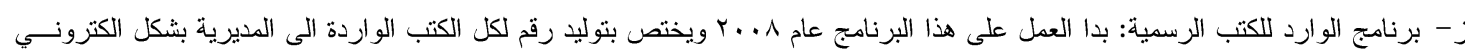
وحفظها بقاعدة بيانات خاصة بذلك.

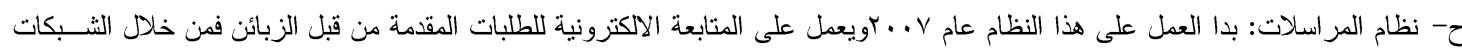

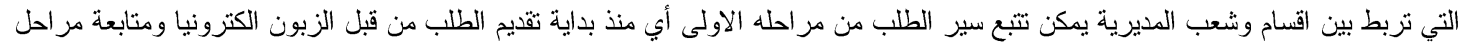

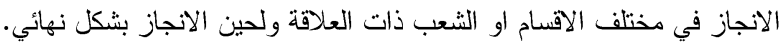

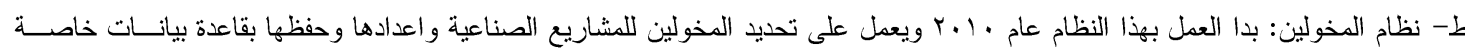
بذلك. ي- نظام الارشفة الالكترونية: بدا العمل بهذا النظام عام ع ا ب ب ويعمل على ارشفة كافة الوثائق و المستمكات العائدة للمشروع الصناعي واتاحتها

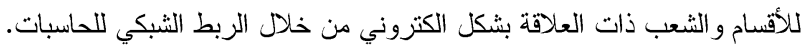

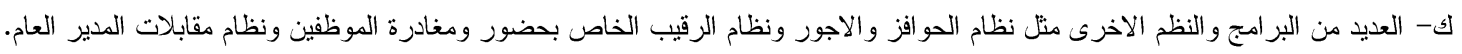

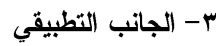

نم استخدام الاستبانة كأداة رئيسة لجمع البيانات عن عينة البحث اذ تم توزيعها على عينة عشو ائية من العاملين في المديرية العامــة للتنميــة الصناعية احتوت على rr سؤال تختص بمتغيرات البحث ومن خلال عرضها جميعها على مقياس ليكرت الخماسي أمكن تحديد الفقرات التالية:

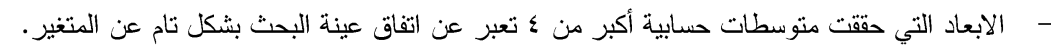

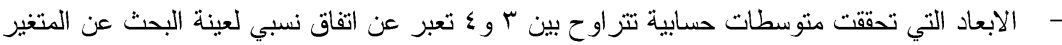

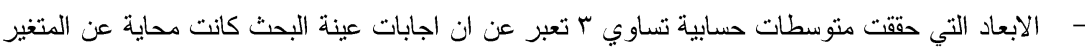

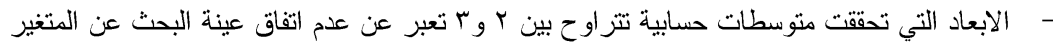

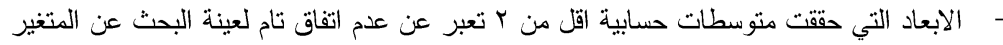

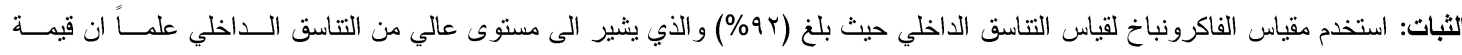

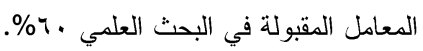

1. ب : : محور الإدارة الاكترونية تضمن محور الادارة الاككترونية على ^ا سؤال توزعت على أربع مكونات وهي عناصر الادارة الالكتروني وكما مبين في الفقرات الاتية.

1- الأوساط الحسابية والاحر اف المعياري والتباين لعنصر لعثاد الحاسوب جدول (•) الأوساط الحسابية والاحرر افات المعيارية والتباين لعنصر عتاد الحاسوب

\begin{tabular}{|c|c|c|c|c|}
\hline التباين & الاحر اف المعياري & |الوسط الحسابي & 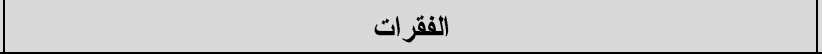 & $ت$ \\
\hline 1.418 & 1.191 & 3.63 & تتوفر في المديرية الاجهزة والمعدات اللازمة لتطبيق الادارة الاكترونية. & 1 \\
\hline 1.270 & 1.127 & 3.52 & لـعتمد المديرية على اجهزة ومعدات منطورة ومحدثة باستمر ار. & 2 \\
\hline 1.219 & 1.104 & 3.73 & لِمكن ان تعلد المديرية على توفير التجهيزات اللازمة لمواجهة الحوادث والازمات التـي & 3 \\
\hline 1.045 & 1.022 & 3.94 & |نسكاهم الاجهزة والمعدات المتوفرة في المديرية على انجاز الاعمال و المهام بشكل & 4 \\
\hline 1.238 & 1.111 & 3.705 & 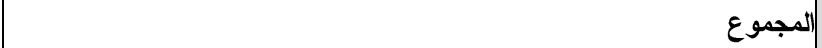 & \\
\hline
\end{tabular}

وتثير معطيات الجدول (0) الى الاتي: - 
عند مر اجعة الأوساط الحسابية والانحر افات المعيارية والتباين لمتغيرات عبارات الاستبانه الخاصة بعنصر عناد الحاسوب يظهر لنا أن كافة

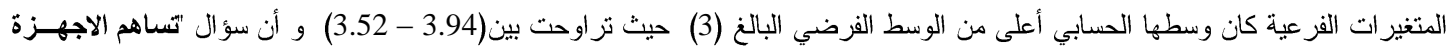

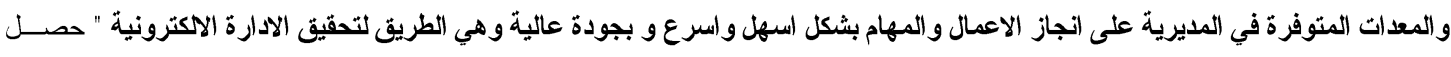

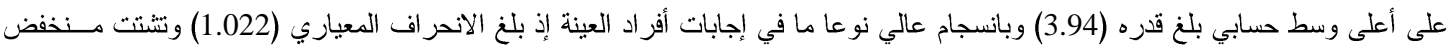

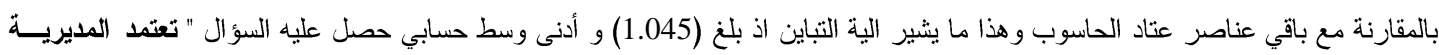

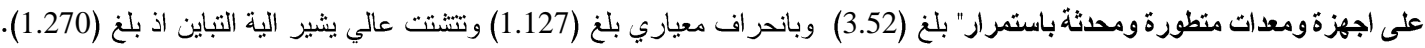

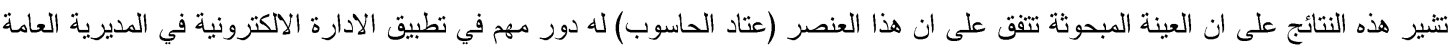
للتتمية الصناعية وهذا ما يشير اليه الوسط الحسابي البالغ (3.705) وهو اعلى من الوسط الفرضي البالغ (3) وبانسجام عالي في إجابات مفردات

العينة يؤكده الانحر اف المعياري البالغ (1.111) وتباين بمقدار (1.238) وهذا يشير الى ان نسبة النتنت في المتوسطات مرتفعة نوعا ما.

r- الأوساط الحسابية والاحصر اف المعياري والتباين لعنصر البرامجيات

جدول (7) الأوساط الحسابية والاحر افات المعيارية والتباين لعنصر البرامجيات

\begin{tabular}{|c|c|c|c|c|}
\hline التباين & الاحمراف المعياري & الوسط الحسابي & 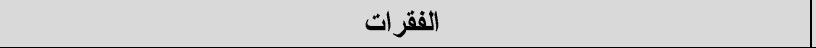 & $ت$ \\
\hline .530 & .728 & 4.27 & تمتلك المديرية قاعدة بيانات على مستوى جميع الأقسام و التشكيلات التنظيمية & 5 \\
\hline .652 & .807 & 3.94 & تحرص المديرية على اعتماد البر امج و النظم المحدثة بشكل دائم. & 6 \\
\hline .901 & .949 & 3.87 & تعمل المديرية على توفير الحماية للبيانات و المعلومات من خلال اعتمادها على & 7 \\
\hline .739 & .860 & 3.58 & تستخدم المديرية انظمة معلومات وبر امجيات متطورة في التعامل سواء كانت بين & 8 \\
\hline .705 & .836 & 3.915 & 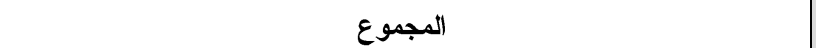 & \\
\hline
\end{tabular}

$$
\text { وتشير معطيات الجدول (T) الى الاتي:- }
$$

عند مر اجعة الأوساط الحسابية والانحر افات المعيارية والتباين لمتغيرات عبارات الاستبانه الخاصة بعنصر البرامجيات يظهر لنا أن كافة

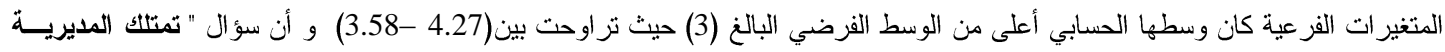

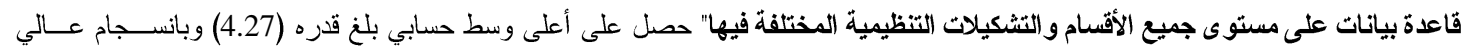

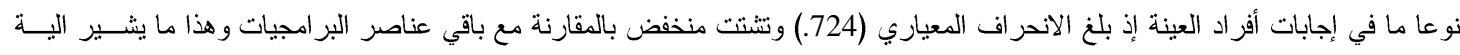

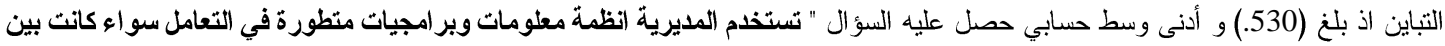
ادار اتها المختلفة او بينهاوبين الزبون " بلغ (3.58) وبانحر اف معياري بلغ (86.) وتتشتت يثير الية التباين اذ بلغ (739.).

تتشير هذه النتائج على ان العينة المبحوثة تتفق على ان هذا العنصر(البرامجيات)له دور مهم في تطبيق الادارة الالكترونية فـي المديريسـة

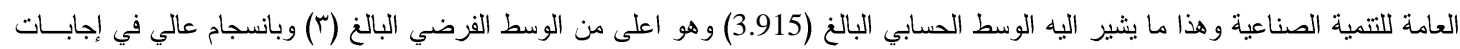

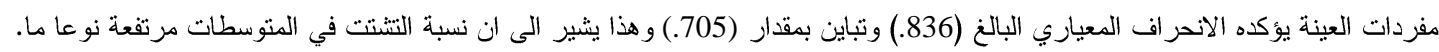


r- الأوساط الحسابية والاحر اف المعياري والتباين لعنصر شبكات الاتصالات جدول V) الأوساط الحسابية والاحمر افات المعيارية و التباين لعنصر شبكات الاتصالات

\begin{tabular}{|c|c|c|c|c|}
\hline التباين & الاتحر اف المعياري & |الوسط الحسابي | & الفقرات & $ت$ \\
\hline .978 & .989 & 3.81 & تمتلك المديرية المعدات و الاجهزة التي توفر شبكة اتصالات فعالة بين اجهزة & 9 \\
\hline 1.249 & 1.118 & 3.89 & تستخدم المديرية موقع الكتروني او مواقع التو اصل الاجتماعي لتحقيق الاتصات ميع الجهات المستفيدة. & 10 \\
\hline 1.695 & 1.302 & 3.24 & تعتمد المديرية على شبكة معلومات داخلية (الاتتر اتت)في التنسيق بين اعمال & 11 \\
\hline 1.531 & 1.237 & 3.76 & |تنجز المديرية تعاملاتها مع الجهات الاخرى باعتماد البريد الاككتروني(الايميل). & 12 \\
\hline 1.363 & 1.161 & 3.675 & المجموع & \\
\hline
\end{tabular}

$$
\text { وتتير معطيات الجدول (V) الى الاتي: - }
$$

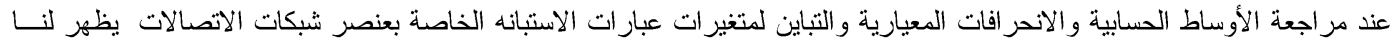

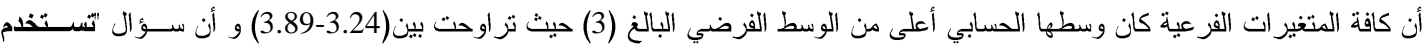
المديرية موقع الكتروني او مواقع التو اصل الاجتماعي لتحقيق الاتصالات مع الجهات المستفيدة" حصل على أعلى وسط حسابي بلغ قدره (3.89)

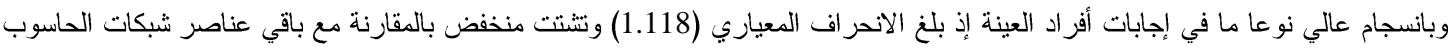

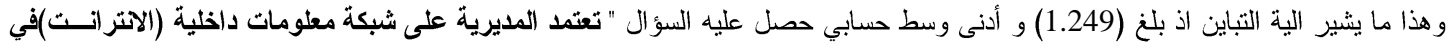

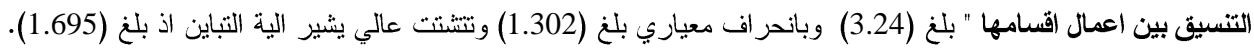

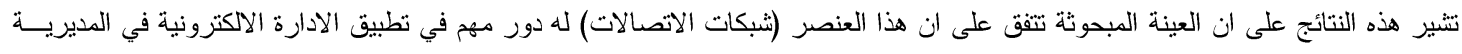

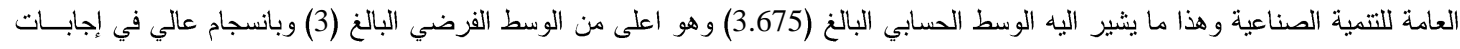

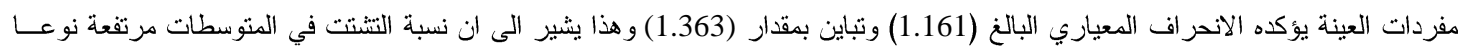

ع - الأوساط الحسابية والاحر اف المعياري والتباين لعنصر صناع المعرفة

جدول (^) الأوساط الحسابية والاحر افات المعيارية والتباين لمتغير لعنصر صناع المعرفة

\begin{tabular}{|c|c|c|c|c|}
\hline التباين & 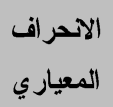 & الوسط الحسابي & الفقر ات & $ت$ \\
\hline 1.102 & 1.050 & 3.56 & تمتلك المديرية الافر اد ذوي المعرفة و الخبرة المطلوبة لاستخدام الحاسوب و الاتصالات & 13 \\
\hline 1.064 & 1.032 & 3.40 & تمتلك ادارة المديرية المعرفة الإدارية و الفنية الملانمتان لتطبيق الإدارة الإكترونية. & 14 \\
\hline 1.233 & 1.111 & 3.44 & تمتلكك المديرية قيادات ادارية قادرة على توجيه العاملين نحو تطبيق الادارة الاكترونية. & 15 \\
\hline .738 & .859 & 3.82 & تهيئ المديرية جميع المتطلبات الإدارية الخاصة بتأهيل وتدريب الموارد البشرية الخاصة بتطبيق الإدارة الإكترونية. & 16 \\
\hline 1.034 & 1.013 & 3.555 & المجموع & \\
\hline
\end{tabular}

$$
\text { وتتير معطيات الجدول (^) الى الاتي:- }
$$

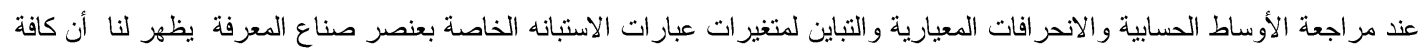

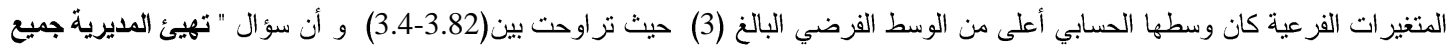

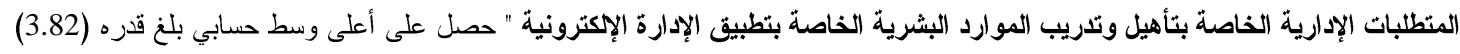

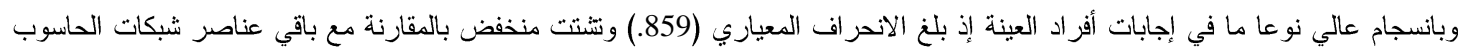


وهذا ما يشير الية التباين اذ بلغ (738.) و أدنى وسط حسابي حصل عليه السؤال "تمتلك المديرية قيادات ادارية قادرة على توجيه العاملين نحسو

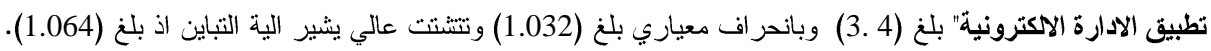

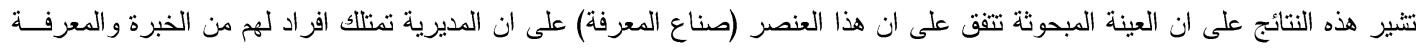

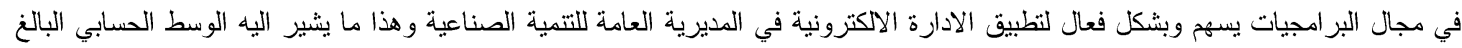

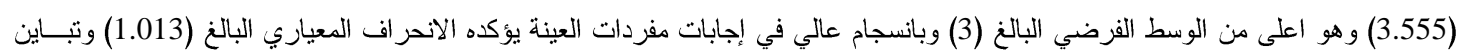

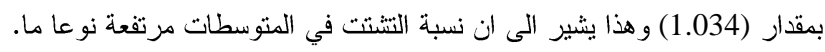

هـ - خلاصة نتائج الأوساط الحسابية والانحر افات المعيارية لمحور الإدارة الاكترونية جدول (9) الأوساط الحسابية والاحرر افات المعيارية والتباين لعناصر الادارة الاكترونية

\begin{tabular}{|c|c|c|c|c|}
\hline التباين & الاحـر اف المعياري & الوسط الحسابي & العنصر & $ت$ \\
\hline 1.238 & 1.111 & 3.705 & عتاد الحاسوب & 1 \\
\hline 0.705 & 0.836 & 3.915 & البر امجيات & r \\
\hline 1.363 & 1.161 & 3.675 & شبكات الاتصالات & $r$ \\
\hline 1.034 & 1.013 & 3.555 & صناع المعرفة & $\varepsilon$ \\
\hline 1.085 & 1.030 & 3.7125 & المجموع & \\
\hline
\end{tabular}

وتتثير معطيات الجدول (9) الى الاتي: -

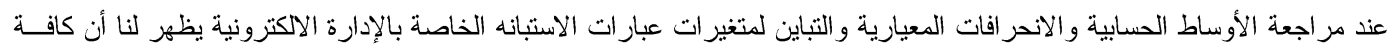

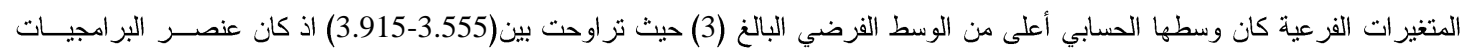

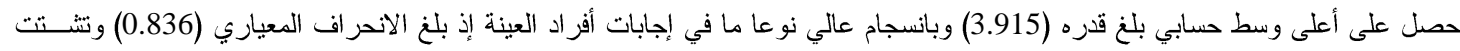

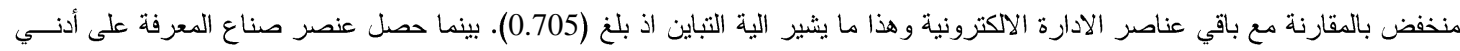

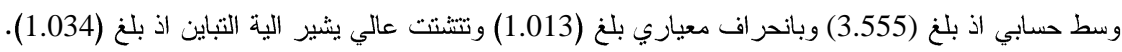

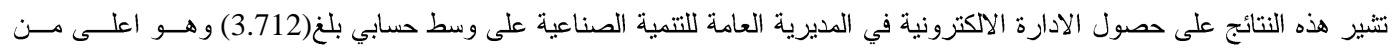
الوسط الفرضي البالغ (ץ) وبانسجام عالي في إجابات مفردات العينة يؤكده الانحر اف المعياري البالغ (1.03) وتباين بمقدار (1.085). r.r

تضمن محور التتظيمي على 1/ سؤال توزعت على أربع من عو امل النجاح التتظيمي وكما مبين في الفقرات الاتية.

1- الأوساط الحسابية والاحر اف المعياري والتباين لعامل (لسرعة)

جدول (· 1) الأوساط العسابية والاحر افات المعيارية والتباين لعامل السرعة

\begin{tabular}{|c|c|c|c|c|}
\hline التباين & الاحمراف المعياري & الوسط الحسابي & الفقرات & $ت$ \\
\hline .561 & .749 & 4.11 & لسعاعد البر امجيات والاجهزة و المعدات المعتمدة حالياً في المديرية على انجاز المهام & 17 \\
\hline .639 & .799 & 4.13 & 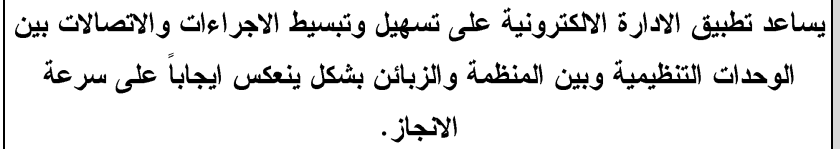 & 18 \\
\hline .637 & .798 & 4.23 & يساعد تطبيق الادارة الاكترونية على اعداد التقارير المطلوبة بوقت أقصر ودقة & 19 \\
\hline .604 & .777 & 4.23 & | يساعد تطبيق الادارة الاكترونية في العصول على المعلومات في اي وقت ومكان. & 20 \\
\hline 0.61 & 0.78 & 4.175 & المجموع & \\
\hline
\end{tabular}




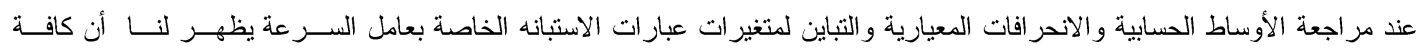

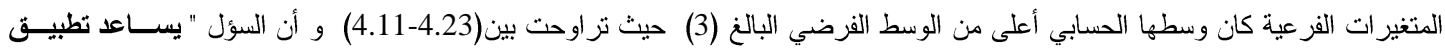
الادارة الاكترونية في الحصول على المعلومات في اي وقت ومكان " حصل على أعلى وسط حسابي بلغ قدره (4.23) وبانسجام عالي نو عا ما في

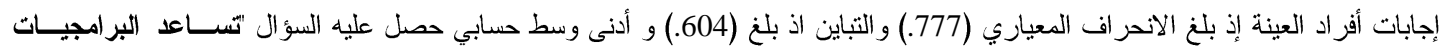

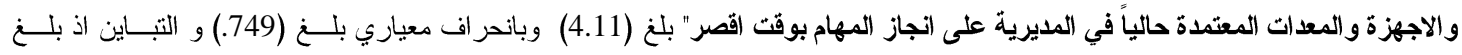

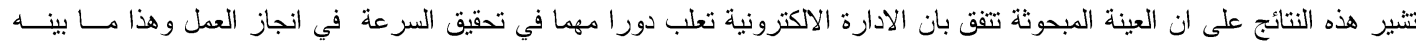
الوسط الحسابي المرتفع اذ بلغ (V0. أع) و انحر اف معياري بمقدار (0.78) و التباين (0.61).

r- الأوساط الحسابية والاحر اف المعياري والتباين لعامل (المرونة)

جدول (11) الأوساط الحسابية والاحمر افات المعيارية والتباين لعامل المرونة

\begin{tabular}{|c|c|c|c|c|}
\hline التباين & 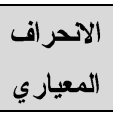 & 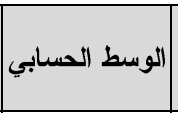 & الفقر ات & ت \\
\hline .954 & .977 & 3.35 & |تمتلك المديرية افر اد متخصصون ذوي الخبرة و الاختصاص في تطوير البر امجيات التي & 21 \\
\hline .613 & .783 & 4.10 & من خلال اعتماد الادارة الاكترونية يمكن للمديرية تقديم الخدمات الجديدة في الوقت & 22 \\
\hline .880 & .938 & 3.81 & |تستخدم تقنيات الادارة الاكترونية في التغذية العكسية لتذليل الصعوبات التي تظهر اثناء & 23 \\
\hline .654 & .808 & 4.26 & توفر الادارة الاككترونية الكثير من المرونة والعرعة في انجاز المهام والواجبات. & 24 \\
\hline 0.775 & 0.876 & 3.88 & المجموع & \\
\hline
\end{tabular}

وتشيز معطيات الجدول (11) الى الاتي: -

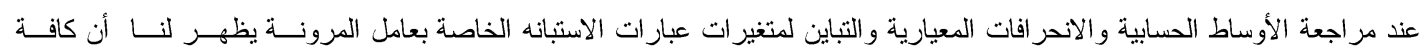

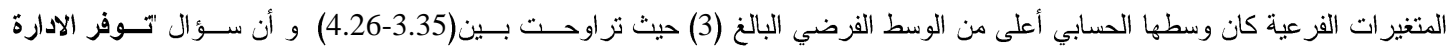

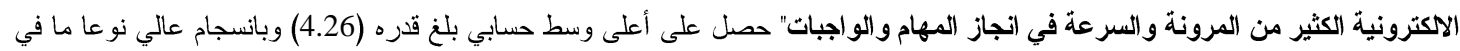

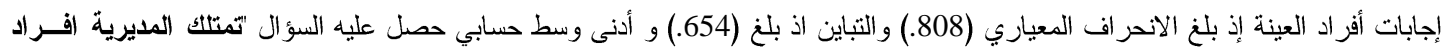

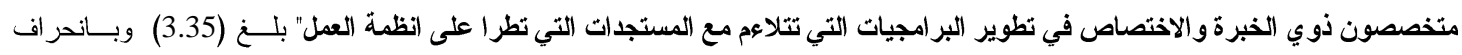
معياري بلغ (977.) وتتشتت عالي يشير الية التباين اذ بلغ (954.).

تتثير هذه النتائج على ان العينة المبحوثة تتفق بان الادارة الاككترونية تعلب دورا مهما في تحقيق المرونة في العمل وهذا ما بينه الوسـط الحسابي اذ بلغ (3.88) و انحر اف معياري بمقدار (0.876) وان لإنة التباين (0.775). 
r- الأوساط الحسابية والاحمر اف المعياري والتباين لعامل (التكامل)

جدول (r ا ) الأوساط الحسابية والاحمر افات المعيارية والتباين لعامل التكامل

\begin{tabular}{|c|c|c|c|c|}
\hline التباين & | الاحر اف المعياري & |الوسط الحسابي | & الفقرات & 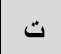 \\
\hline .637 & .798 & 4.05 & تساعد الانظمة و البر امج المتوفرة في المديرية من زيادة التعاون بين اقسام المديرية & 25 \\
\hline .449 & .670 & 4.10 & تساهم الادارة الاككترونية في تكامل الأنظمة بشكل ينعكس على تسريع وتيرة العمل. & 26 \\
\hline .619 & .787 & 3.94 & تسهل الادارة الاكترونية من تحقيق التكامل الافقى و العمودي بين المستويات الادارة & 27 \\
\hline .793 & .891 & 3.84 & تساهم الادارة الاكترونية في تحقيق التواصل مع البيئة الخارجية و التكيف معها. & 28 \\
\hline 0.624 & 0.786 & 3.982 & 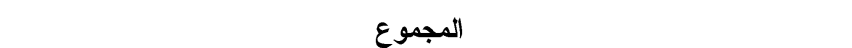 & \\
\hline
\end{tabular}

وتشير معطيات الجدول (r ا الى الاتي:عند مر اجعة الأوساط الحسابية والانحر افات المعيارية و التباين لمتغيرات عبار اتلات الاستبانه الخاصة بعامل التكامل يظهر لنا أن كافة المتغيـرات

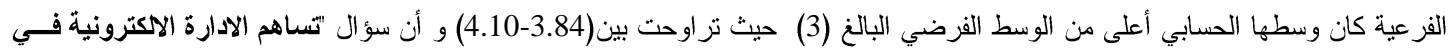

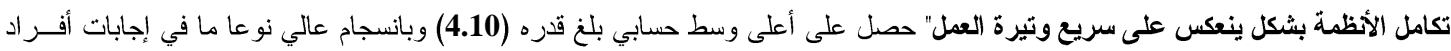

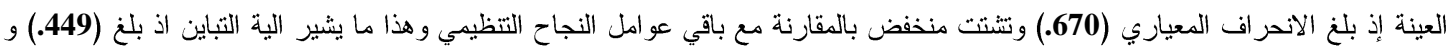

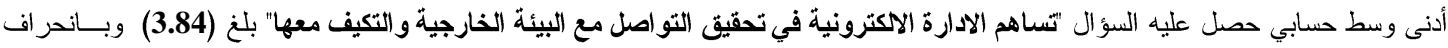

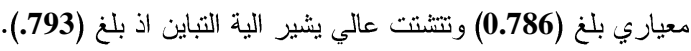
تنتير هذه النتائج على ان العينة المبحوثة تتفق بان الادارة الاكلكترونية تعلب دورا مهما في تحقيق التكامل بين الوظائف في المديرية العامة للتنمية

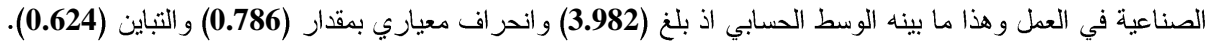

؛ - الأوساط الحسابية و الآحر اف المعياري والتباين لعامل (الابتكار)

جدول (T ا I الأوساط الحسابية والاحر افات المعيارية و التباين لعامل الابتكار

\begin{tabular}{|c|c|c|c|c|}
\hline 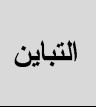 & 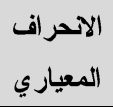 & | الوسط الحسابي & 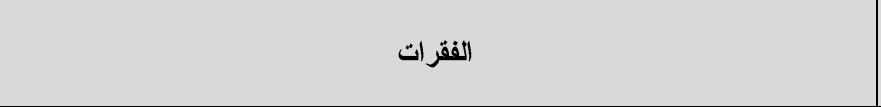 & $ت$ \\
\hline .820 & .905 & 4.00 & |تسعى المديرية من خلال اعتمادها على التكنولوجيا الحديثة الى تبني افكار جديدة لتطوير & 29 \\
\hline .562 & .750 & 4.21 & يشجع الاعتماد على اجهزة الحاسوب و الثبكات على انجاز بر امجج جليدة تساعد على & 30 \\
\hline .440 & .663 & 4.23 & يشجع الاعتماد على اجهزة الحاسوب و الثبكات على تقديم خدمات جديدة. & 31 \\
\hline .449 & 670 & 4.24 & يشجع الاعتماد على اجزةة الحاسوب و الثبكات على انجاز المهام و الثواجبات بطرق واساليب جديدة. & 32 \\
\hline 0.567 & 0.747 & 4.17 & 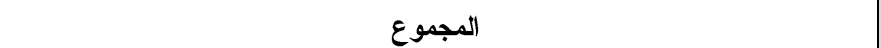 & \\
\hline
\end{tabular}

وتشير معطيات الجدول (r ا الى الاتي: -

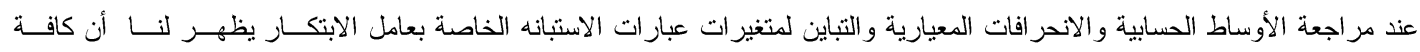

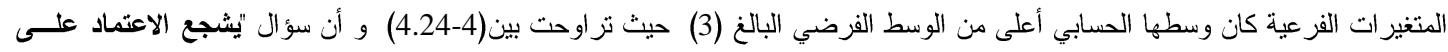

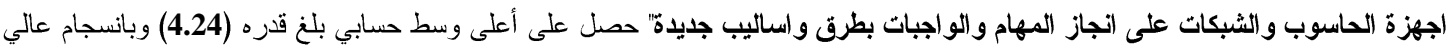

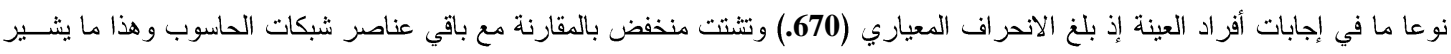


الية التباين اذ بلغ (449.) و أدنى وسط حسابي حصل عليه السؤال "تسعى المديرية من خلال اعتمادها على التكنولوجيا الحديثة الى تبني افــار

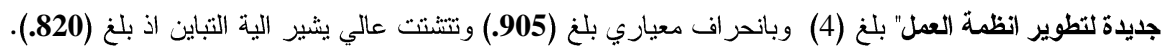

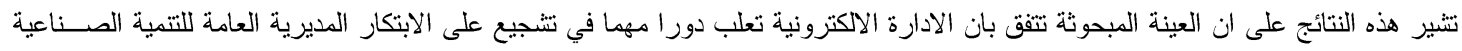

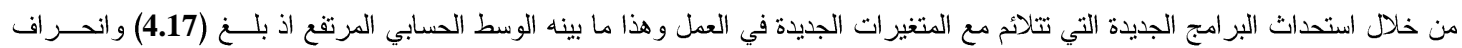

معياري بمقدار (0.747) و النباين (0.567).

ه - خلاصة نتائج الأوساط الحسابية والاتحر افات المعيارية لعوامل النجاح التنظيمي جدول (T ا الأوساط الحسابية والاحر افات المعيارية والثباين لعناصر النجاح التنظيمي

\begin{tabular}{|c|c|c|c|c|}
\hline التباين & الاحصر اف المعياري & الوسط الحسابي & العنصر & $ت$ \\
\hline 0.561 & 0.78 & 4.175 & السرعة & 1 \\
\hline 0.775 & 0.876 & 3.88 & المرونة & r \\
\hline 0.624 & 0.786 & 3.982 & التكامل & $r$ \\
\hline 0.567 & 0.747 & 4.17 & الابتكار & $\varepsilon$ \\
\hline 0.631 & 0.772 & 4.051 & \multicolumn{2}{|l|}{ المجموع } \\
\hline
\end{tabular}

وتتير معطيات الجدول (rآ) الى الاتي: -

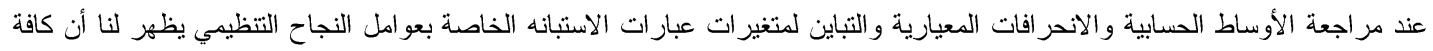

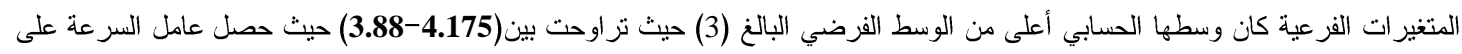

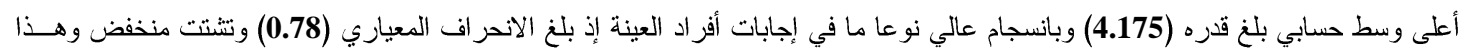

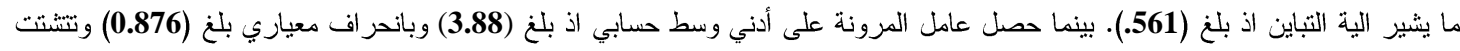
عالي يثير الية التباين اذ بلغ (0.775).

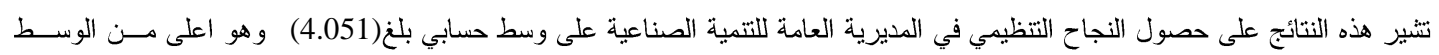
الفرضي البالغ (ץّ) وبانسجام عالي في إجابات مفردات العينة يؤكده الانحر اف المعياري البالغ (0.772) وتباين بمقار (0.631).

r.r: تحليل علاقات الارتباط بين عناصر الإدارة الاكترونية والنجاح التنظيمي

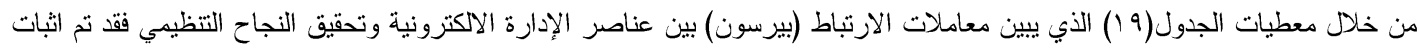

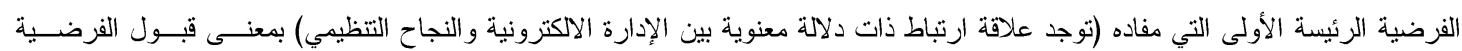

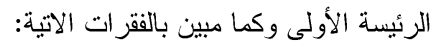

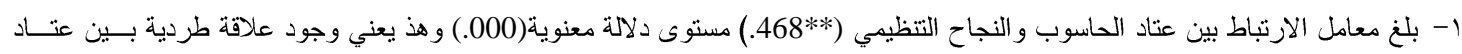

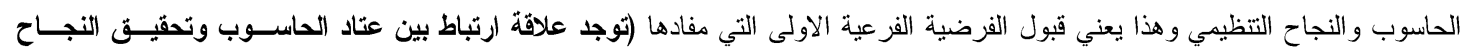

(التنظيمي).

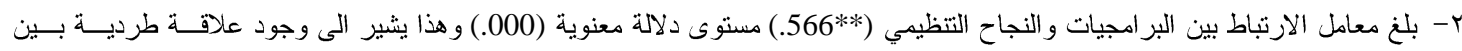

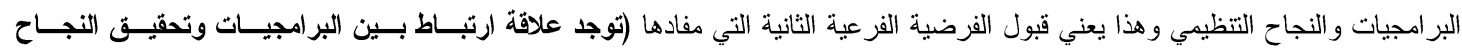
(التنظيمي)

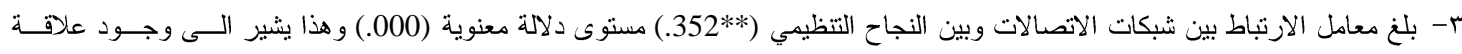
طردية بين شبكات الاتصالات و النجاح النتظيمي وهذا يعني قبول الفرضية الفرعية الثالثاتئة التي مفادها (توجد علاقة ارتباط بين شبكات الاتصالات

وتحقيق النجاح التنظيمي).

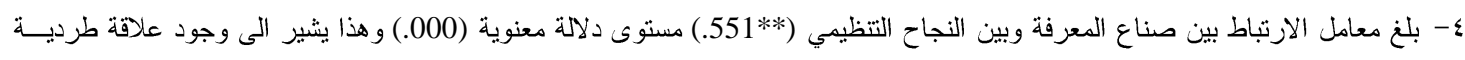

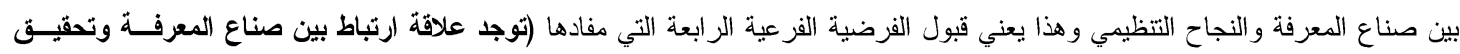
(النجاح النتظيمي). 
جدول (9 1 ) خلاصة قيم الارتباط بين عناصر الادارة الاكترونية و النجاح التنظيمي

\begin{tabular}{|c|c|c|c|}
\hline \multicolumn{3}{|c|}{ النجاح التنظيمي } & \multirow{2}{*}{ الإدارة الالكترونية } \\
\hline الدلالة الاحصائية & المعنوية & الارتباط & \\
\hline 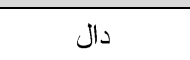 & .000 & $.468^{* * *}$ & عتاد الحاسوب \\
\hline 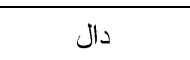 & .000 & $.566^{* *}$ & البر امجيات \\
\hline دال & .000 & $.352^{* *}$ & شبكات الاتصال \\
\hline 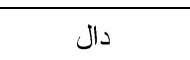 & .000 & $.551^{* *}$ & صناع المعرفة \\
\hline
\end{tabular}

؛.بr: تحليل علاقات التأثير بين عناصر الإدارة الاكترونية و النجاح التظظيمي

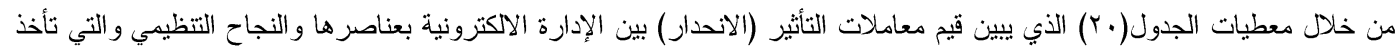
$\mathrm{Y}=\alpha+\beta \mathrm{X}$

الثكل الاتي: حيث ان:

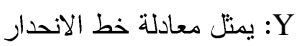
Q م: قيمة الثابت المئرة X فقد تم اثبات الفرضية الرئيسة الثانية والتي مفادها (وجود علاقة تأثثر بين عناصر الإدارة الالكترونية وتحقيق النجاح التنظيمي) بمعنى قبـــول الفرضية الرئيسة الثانية وكما مبين في الفقرات الاتية: التئية

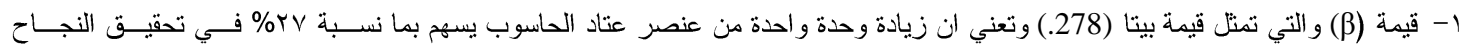

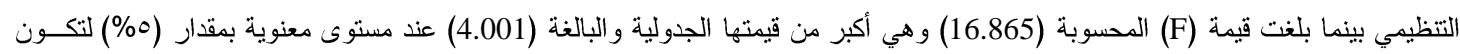
$\mathrm{Y}=0.468+0.278 \mathrm{X}_{1}$ معادلة الميل لعنصر عتاد الحاسوب كما في الثكل الاتي: وهذا يثبت الفزضية التي مفادها وهذا يثبت الفرضية التي مفادها (توجد علاقة تأثير ذات دلالة معنوية بين عثاد الحاسوب وتحقيق النجـاح

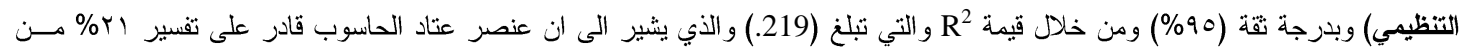

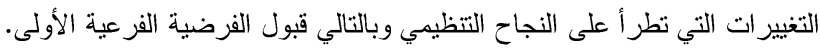

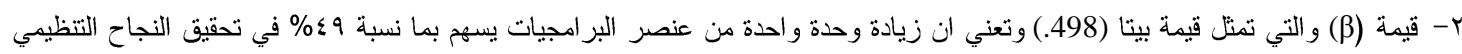

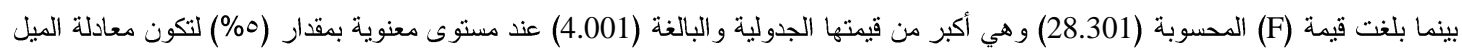
$\mathrm{Y}=0.566+0.498 \mathrm{X}_{1}$

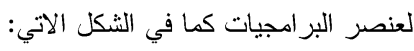
و هذا يثبت الفرضية التي مفادها وهذا يثبت الفرضية التي مفادها (توجد علاقة تأثير ذات دلالة معنوية بين البرامجيات وتحقيق النجاح التنظيمي)

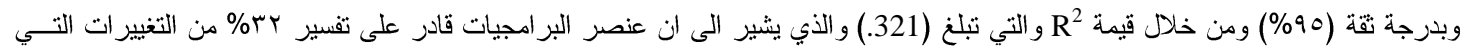

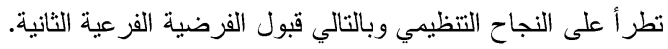

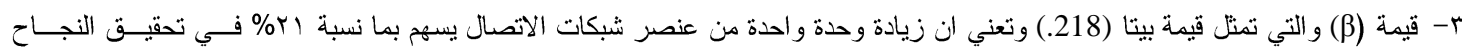

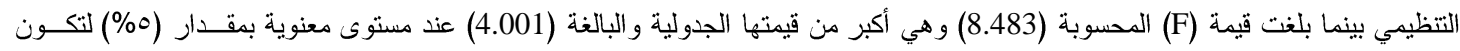
$\mathrm{Y}=0.352+0.218 \mathrm{X}_{1}$ معادلة الميل لعنصر شبكات الاتصالات كما في الثكل الاتي:

و هذا يثبت الفرضية التي مفادها و هذا يثبت الفرضية التي مفادها (توجد علاقة تأثثر ذات دلالة معنوية بين شبكات الاتصالات وتحقيـق النجــاح

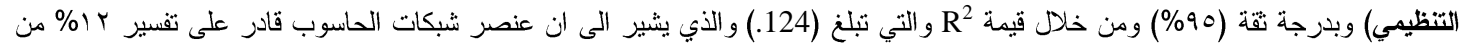

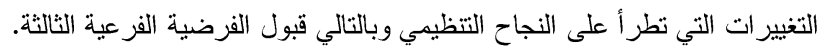

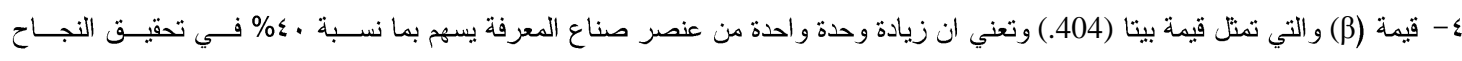

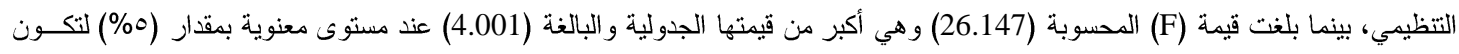
$\mathrm{Y}=0.551+0.404 \mathrm{X}_{1}$

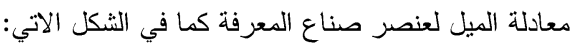

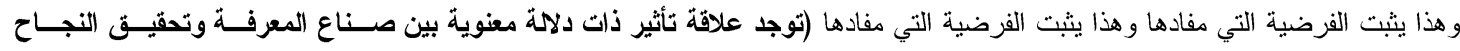

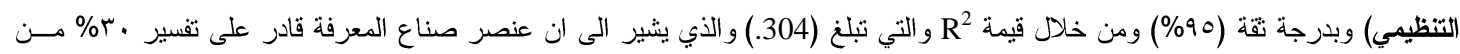

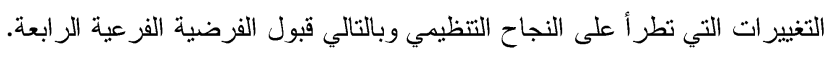


جدول (·r) خلاصة قيم علاقة التأثير بين عناصر الادارة الاكترونية والنجاح التنظيمي

\begin{tabular}{|c|c|c|c|c|}
\hline \multicolumn{4}{|c|}{ النجاح التنظيمي } & \multirow[t]{2}{*}{ عناصر الإدارة الاكترونية } \\
\hline المعنوية & $\mathbf{R}^{2}$ & $\mathbf{F}$ & B & \\
\hline .000 & .219 & 16.865 & .278 & عتاد الحاسوب \\
\hline .000 & .321 & 28.301 & .498 & البر امجيات \\
\hline .005 & .124 & 8.483 & .218 & شبكات الاتصال \\
\hline .000 & .304 & 26.147 & .404 & صناع المعرفة \\
\hline
\end{tabular}

\section{ع - الاستنتاجات و التوصيات}

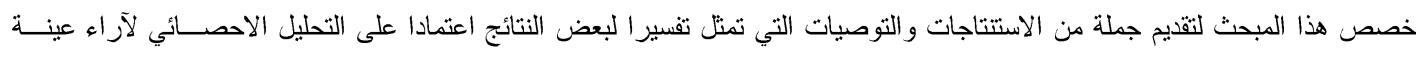

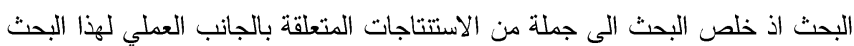

اولاً: الاستنتاجات

1- تعد الإدارة الاككترونية بعناصرها المختلفة مدخلا ملائما لتحسين أنظمة العمل بما ينعكس على أداء المنظمة بشكل عام.

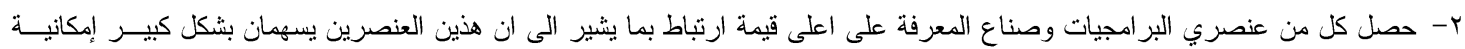
تحقيق النجاح التنظيمي.

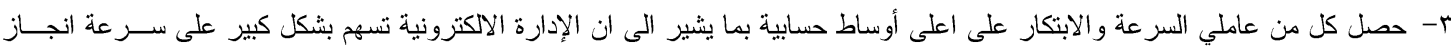
الاعمال و التشبيع على الابتكار لإيجاد الحلول المناسبة للمشكلات التي تطر ألى ألى على أنظمة العمل.

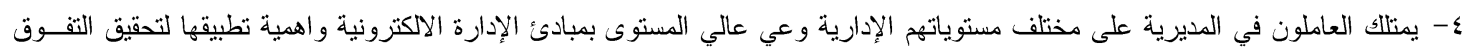
والنجاح. ه- لوحظ وجود اهتمام واضح لإدارة المديرية بتأهيل الموارد البشرية لنطبيق الادارة الالكترونية من حيث توفير الاماكن والمساحات الضرورية الممارسة الادارة الالكترونية و المتطلبات الادارية.

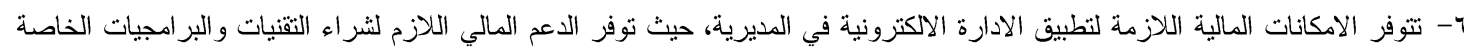

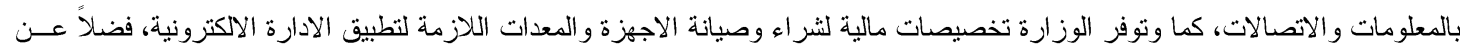

توفير تخصيصات مالية لأشر الك الموظفين في بر امج تدريبية تخصيصية ذات صلة باستعمال تقنيات الادارة الالكترونية.

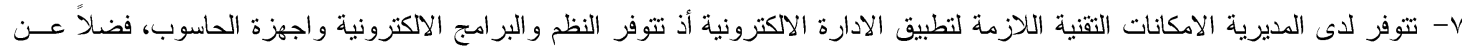

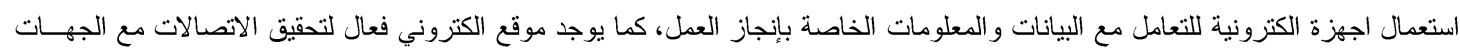
الاخرى.

1- تحرص المديرية العامة للتنمية الصناعية على توفير البرامجيات الحديثة والامينة الكفيلة بحفظ بياناتها من التلف او الضياع.

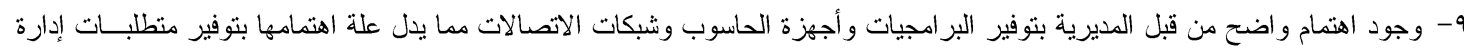
الكترونية فاعلة تتعكس على أداء الاعمال بفاعلية أكبر من خلال حل المشاكل التي تظرأ على أنظمة العمل مما يساعد على تحسين العين اداءها الفعلي.

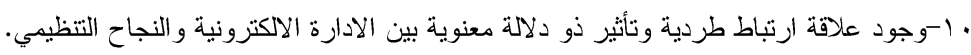
ثنانياً: التوصيات

تأسيسا على ما توصل اليه من استتناجات يمكن ان يخرج البحث باتلتوصيات الاتية:

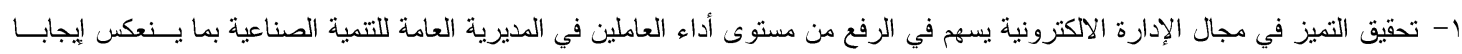
على تحقيق النجاح التنظيمي. r- التوسع في استخدام الأنظمة الالكترونية الحديثة والأجهزة و البر امجيات المتطورة وبناء قو اعد بيانات المختلفة.

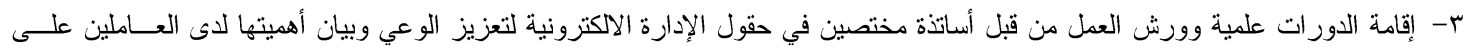

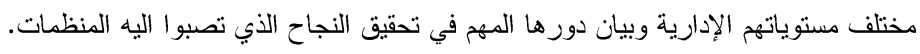

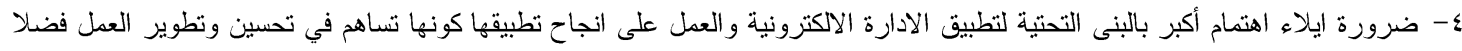

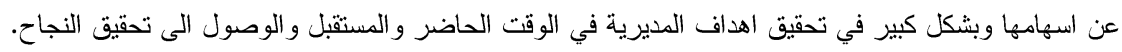

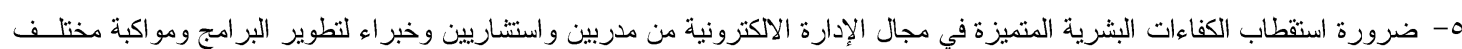
التطور ات التكنولوجية. צ- التركيز على توعية العاملين وتطوير ومهار اتهم وقدرتهم في مجال بر امج الحاسوب المختلفة ذات العلاقة بعمل المديرية لتحقيق التميـز فــي ادائهم لأعمالهم ومن ثم تحقيق مستويات متميزة في أداء المديرية. 
V- العمل على إجر اء قياس نسبة النجاح التتظيمي للمديرية كل ستة أشهر بالاعتماد على المؤشر ات المتعلقة بتقييم الاداء فيما يتعلق بالأنظمــة الاكترونية المعتدة في المديرية وأبعاد النجاح التتظيمي من أجل تدارك الأخطاء التي قد تقع بها المديرية وقبل وقو عها في إثاء العمل.

\section{CONFLICT OF INTERESTS}

\section{There are no conflicts of interest}

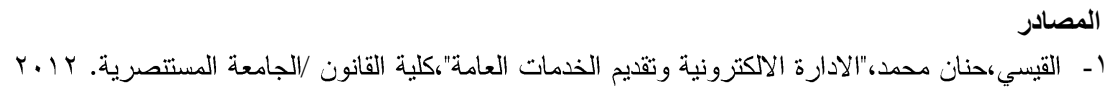
2- Ellatif, Huthaifa Abdelkarim \& Ahmed, Sammani Abdulmutalib,"Configuration, Functions and Role in Improving Performance of Arab Institutions and Organization", International Journal of Computer Applications (0975 - 8887), Volume 80 - No.6, October 2013.

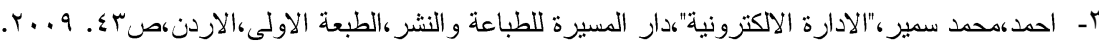

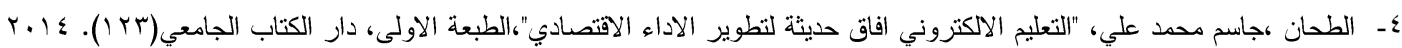

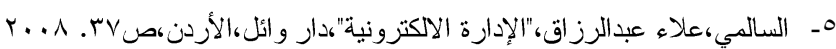

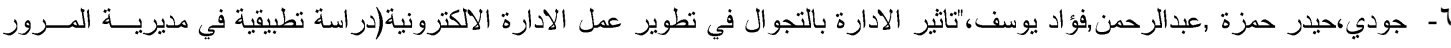

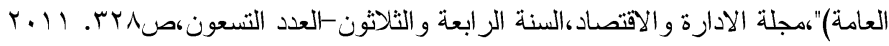

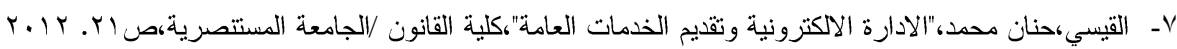

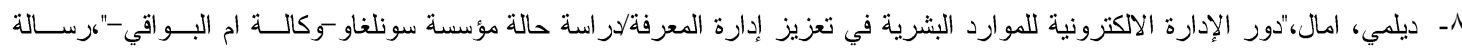

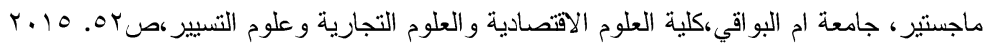

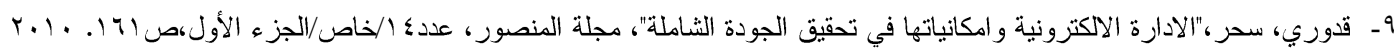

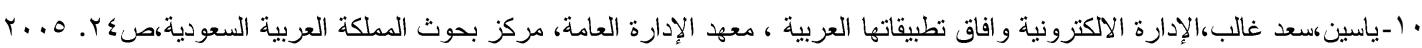

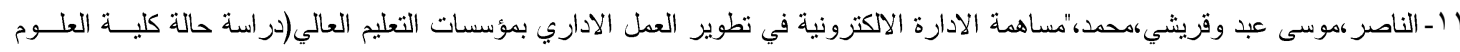

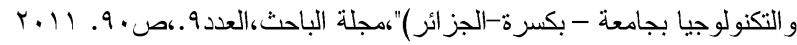
12- N. Rawash, Hassan," Electronic Management's Contribution to the Development of Managerial Functions",Academic Research International Vol. 5(5),p216. 2014.

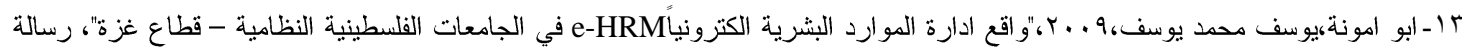

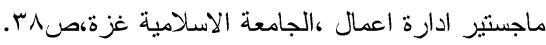

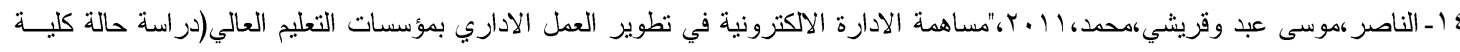

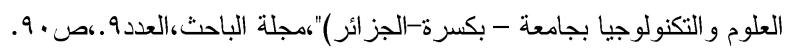

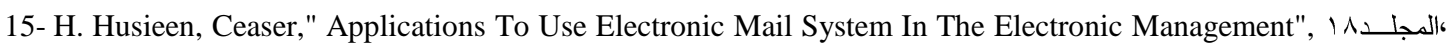
2014.

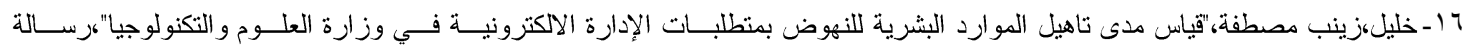

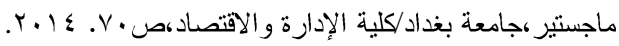

Vا محمد،سعيد عبدالله، فتحي، عبدالعزيز الطيب،"نموذج الإدارة الالكترونية - مدخل ستر اتيجيلتعزيز استراتيجية الريادة (دراسة حالة في شركة

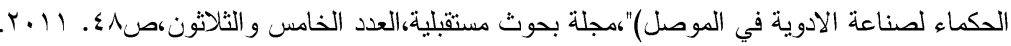

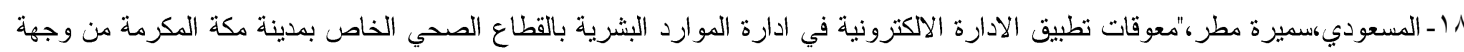

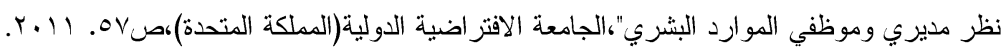

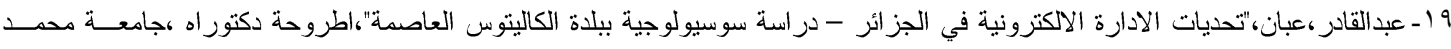

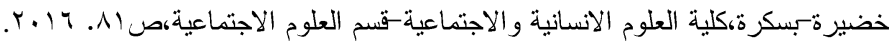

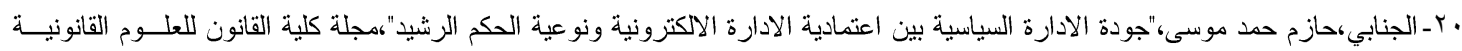

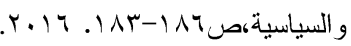
آץ-شريف،علي مصلحي ومحمد،منير محمد و أبو خشبة، محمد محمود،"الإدارة في منظمات الاعمال واسس الرقابة عليها"،دار التعليم الجـامعي

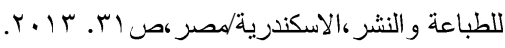

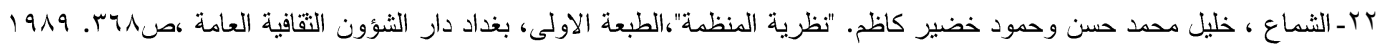
23- Alhodhaibi, ibrahim \& barakat,abdullah, "the impact of organizational knowledge strategies in deliberating of organizational success among managers in saudi arabian industrial companies", arab economics and business journal,p11. 2015.

24- L. Daft, richard, "organization theory and design",tenth edition, library of congress control number: 2009921278, printed in the united states of America,p260-261. 2010.

25- Ronald R. Sims, "Organizational Success through Effective Human Resources Management"-Quorum Books, British Library Cataloguing in Publication Data is available,p13. 2008

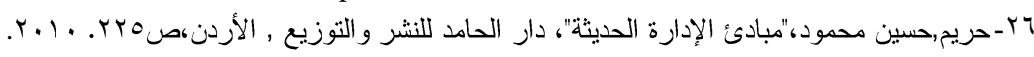


27- Yao, Liu \& Bin Othman,Ahmad \& N Aballa,Ahmed \& R. Mahdi, Omar, "E-management development and deployment strategyfor future organization ", African Journal of Business Management Vol. 5(16), pp. 6657-6667, 18August,p6658. 2011

28- Moseley, Alphronzo, "Redesigning Your Organization for SuccessShift to a New Paradigm ", Leadership Advance Online- Issue XVI, Spring,p3-6. 2009. 